\title{
First report of Mid Ordovician (Darriwilian) cephalopods from the Saluk Mountains, southern Kopet-Dagh Region, north-east Iran
}

\author{
David H. Evans, Mansoureh Ghobadi Pour, Leonid E. Popov \& Had Jahangir
}

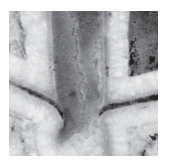

\begin{abstract}
An assemblage of orthoconic cephalopods collected from oolitic ironstones at the base of the Pelmis Formation (New) of the Saluk Mountains of the southern Kopet-Dahg Region of north-eastern Iran indicate that the base of the Pelmis Formation is likely to be Darriwilian in age. Preservation of the assemblage suggests that it is time averaged and may represent a condensed deposit. The assemblage consists of a single endoceratid, several members of the Orthoceratida as well as an indeterminate taxon. Overall, the assemblage shows affinities with South China and Baltica, as well as with other Middle Ordovician cephalopod assemblages recorded from Iran. - Key words: Ordovician, Darriwilian, Pelmis Formation, Cephalopoda, Orthoceratida, palaeobiogeography, peri-Gondwana, Kopet-Dagh, Iran.
\end{abstract}

Evans, D.H., Ghobadi Pour, M., Popov, L.E. \& Jahangir, H. 2021. First report of Mid Ordovician (Darriwilian) cephalopods from the Saluk Mountains, southern Kopet-Dagh Region, north-east Iran. Bulletin of Geosciences 96(2), 139-158 (9 figures, 1 table). Czech Geological Survey, Prague. ISSN 1214-1119. Manuscript received July 27, 2020; accepted in revised form January 14, 2021; published online February 7, 2021; issued April 11, 2021.

David H. Evans, Natural England, Rivers House, East Quay, Bridgwater, Somerset TA6 4YS, United Kingdom; david. evans@naturalengland.org.uk•Mansoureh Ghobadi Pour, Department of Geology, Faculty of Sciences, Golestan University, Golestan, Iran and Department of Geology \& National Museum of Wales, Cathays Park, Cardiff CF10 3NP, United Kingdom - Leonid E. Popov, Department of Natural Sciences, National Museum of Wales, Cathays Park, Cardiff CF10 3NP, United Kingdom • Hadi Jahangir, Department of Geology, Faculty of Sciences, Ferdowsi University, Azadi Square, Mashhad 91775-1436, Iran

Orthoconic cephalopods are amongst the most common components of Iranian Ordovician faunas. They have been documented from a number of localities varying in age from the late Tremadocian to mid Katian (Dastanpour et al. 2006, Evans et al. 2013, Bogolepova et al. 2014, GhavidelSyooki et al. 2015, Popov et al. 2015). A moderately rich cephalopod fauna was recently described from the Silurian (Aeronian) of South Kopet-Dagh (Evans et al. 2015). Ordovician cephalopods have not been documented from that South Kopet-Dagh. The present study is focused on a new Mid Ordovician (Darriwilian) orthoconic cephalopod fauna recently recovered in the eastern Saluk Mountains of South Kopet-Dagh, from a unit consisting of oolitic ironstones that represent a distinct marker horizon at the base of the newly designated Pelmis Formation.

\section{Geological setting}

The presence of Ordovician deposits in the Saluk Mountains, south of the city of Bojnurd in North Khorosan Province was first reported by Afshar-Harb (1979), who assigned them to the Lashkarak and Ghelli formations.
The occurrence of Ordovician conodonts and brachiopods in the Ordovican rocks exposed along the Kalat valley was first documented by Ahmadzadeh-Heravi (1983) who confirmed the presence of Upper Ordovician deposits in Kopet-Dagh.

Recent studies of the Ordovician geology of the Saluk Mountains have revealed significant palaeogeographical differentiation in the lithostratigraphical successions throughout the area; requiring significant revision of the existing lithostratigraphical schemes. In particular, the term Lashkarak Formation, usually applied to the Lower Ordovician deposits of Kopet-Dagh is here confined to the Darriwilian to Upper Ordovician deposits of the Alborz Mountains, including the type area of the Takht-e Soleyman Massif, western Alborz Mountains (Ghobadi Pour et al. 2011). The term Ghelli Formation has been widely applied to the siliciclastic Middle to Upper Ordovician successions in Kopet-Dagh (Ghavidel-Syooki 2001, 2017a, b) and eastern Alborz (for a review, see Ghobadi-Pour et al. 2011). The lower member of the Ghelli Formation in the type section north of the village of Ghelli is a $c .600 \mathrm{~m}$ thick volcano-sedimentary unit of Early to Mid-Ordovician age. A significant portion of the Ghelli Formation is composed 


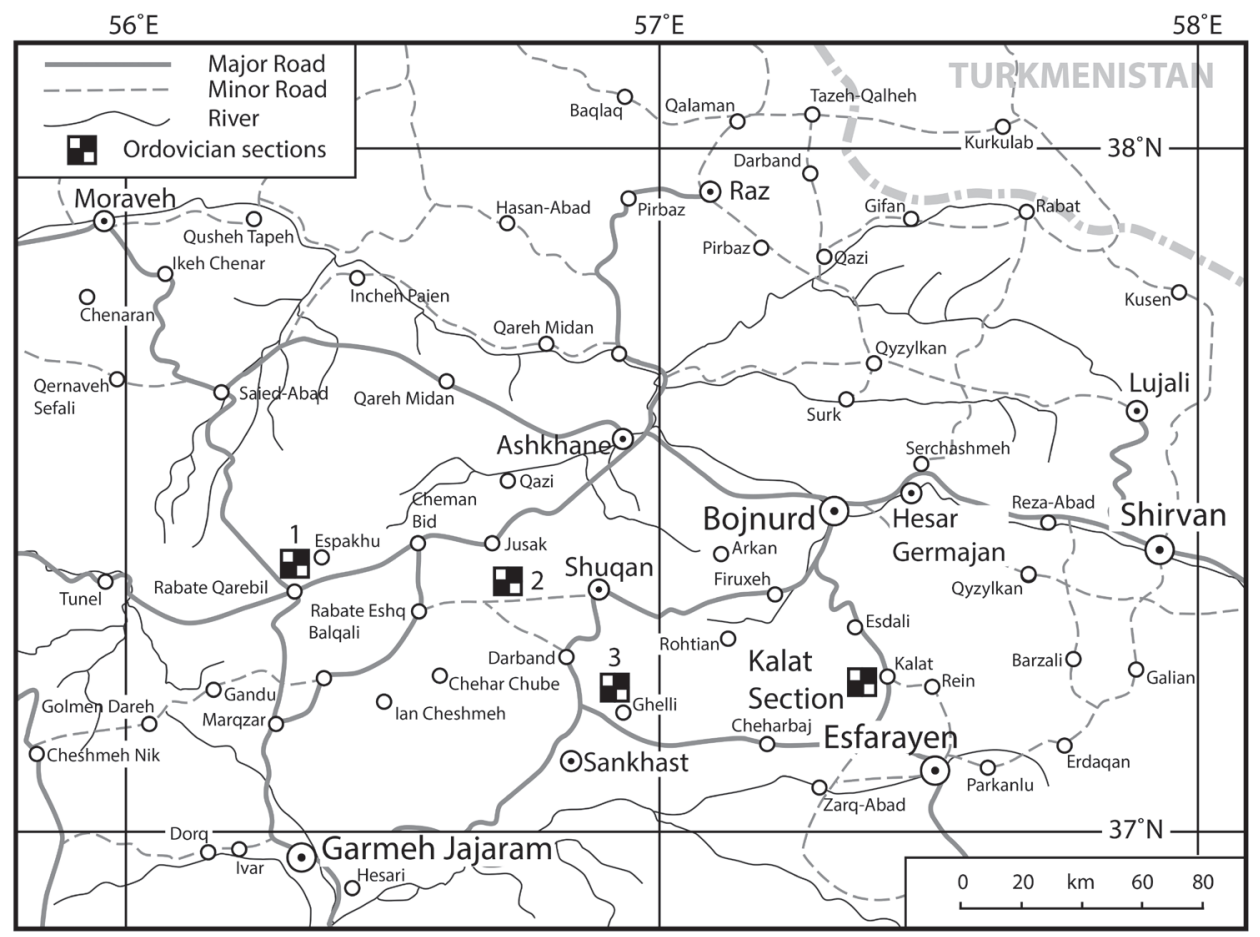

Figure 1. Schematic map of North Khorosan Province, Iran showing the position of the Kalat Section and other Ordovician sections discussed in the paper, including: 1 - Robat-e Qarabil; 2 Navia Inlier; and 3 - Ghelli.

of basalts and tuffs generated by submarine lava flows with a characteristic bed of tuff agglomerates at the base. The middle and upper members of the formation, dated by chitinozoans (Ghavidel-Syooki 2001, 2017a) as Katian to Hirnantian (Tanuchitina fistolusa to Spinachitina oulebsiri zones), are comprised of graded siliciclastic rocks, varying in composition from sandstones to argillites, with two diamictite horizons deposited in the basinal environments. Ghavidel-Syooki (2017a) interpreted these diamictites as glacially derived. An alternative interpretation of these deposits as turbiditic olistostromes was not considered. Nevertheless, such an interpretation requires attention. These are unique features of the Ghelli Formation in the type area that have not been reported from Ordovician successions elsewhere in northern Iran. As a consequence, we consider that the application of the name Ghelli Formation should be restricted to the type area in the western part of the Saluk Mountains. The Middle to Upper Ordovician deposits exposed along the Kalat river valley in the eastern Saluk Mountains are here assigned to the Pelmis Formation (new); proposed and described below.

The biostratigraphy of the Ordovician sediments exposed in the Saluk Mountains is at present largely based on the succession of acritarch and chitinozoan assemblages documented by Ghavidel-Syooki (2001, 2017a, b), and Ghavidel-Syooki \& Winchester-Seeto (2002). The conodont biostratigraphy of the Cambrian to Lower Ordovician (Tremadocian) deposits exposed along the Pelmis Valley was outlined by Jahangir et al. (2015). Information on other groups of the Ordovician fossils reported from

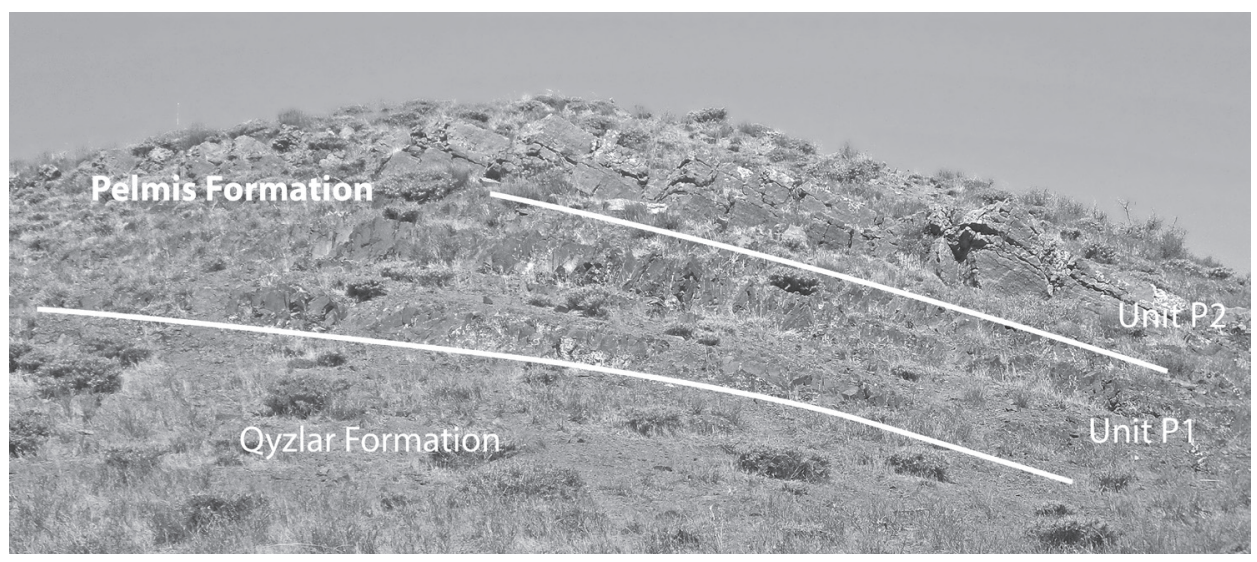

Figure 2. Southerly view of exposure of Units $\mathrm{P} 1$ and $\mathrm{P} 2$ at the base of Pelmis Formation. Unit 2 is comprised of brownish red limestones sandwiched between two beds of oolitic ironstones and is the source of the cephalopods described in the paper. 
the southern Kopet-Dagh Region, including brachiopods, trilobites, gastropods and bivalves remain inadequate.

\section{Pelmis Formation (New)}

Derivation of name. - Refers to the Pelmis Pass near to the location of the type section.

Stratotype. - A natural exposure on the western side of the Kalat river valley in the eastern part of the Saluk area, $c$. $38 \mathrm{~km}$ south of the city of Bojnurd, and c. $490 \mathrm{~m}$ west of the road connecting Bojnurd to Esfarayen (Figs 1, 2). The geographical coordinates of the base of the type section are $37^{\circ} 13^{\prime} 49^{\prime \prime} \mathrm{N}, 57^{\circ} 23^{\prime} 3^{\prime \prime} \mathrm{E}$. The succession at the type section is given in Fig. 3 and Tab. 1.

Lithology. - The lower to mid part of the Pelmis Formation represents a succession of the heterolithic siliciclastic rocks that vary in composition from coarse-grained sandstones to siltstones with horizontal and low angle cross-lamination. A few beds of impure bioclastic limestones of decimetre scale and lenticular beds of pebbly conglomerate are also present. A basaltic tuff overlain by a bed of oolitic ironstone is present at the base of the formation. A thick unit of basaltic volcanic rocks is present in the upper part of the formation within the Ancyrochitina merga Biozone at the Pelmis section. The horizons above the basaltic volcanic rocks comprise mainly moderately bioturbated argillites and siltstones interbedded with fine-grained sandstones.

Distribution and age. - Outside the type area of the eastern Saluk Mountains, the Pelmis Formation is exposed in the tectonic window at the base of the major thrust sheet in the Navia Inlier north-east of the village of Nabiya, where they were originally assigned to the Ghelli Formation by BayetGoll \& Carvalho (2016), and to the north of the village of Robat-e Qarabil (Ghavidel-Syooki \& Borji 2018).

The Darriwilian age of the lower part of the Pelmis Formation is based mainly on the evidence provided by the cephalopod assemblage. The type species of Eosomichelinoceras Chen, 1974 came from the early Katian, Jiaqu Formation of Lin \& Qiu (1982), situated in the Tethyan Himalayas of Southern Xizang, and referred to as the Quanshang Formation by Chen (1984), and taken wrongly

Figure 3. Stratigraphical column of the type section of the Pelmis Formation on the west side of the Kalat river valley, eastern Saluk Mountains, showing the stratigraphical ranges of cephalopod as well as selected trilobite and brachiopod taxa. Lithologies: 1 - sandstones; 2 - intercalated sandstones and siltstones; 3 - intercalated siltstones and limestones; 4 - bioclastic limestones; 5 - grey argillites; 6 - oolitic ironstones; 7 - tuffs; 8 - andesitic to basaltic extrusives; 9 - brachiopod dominated coquinas.

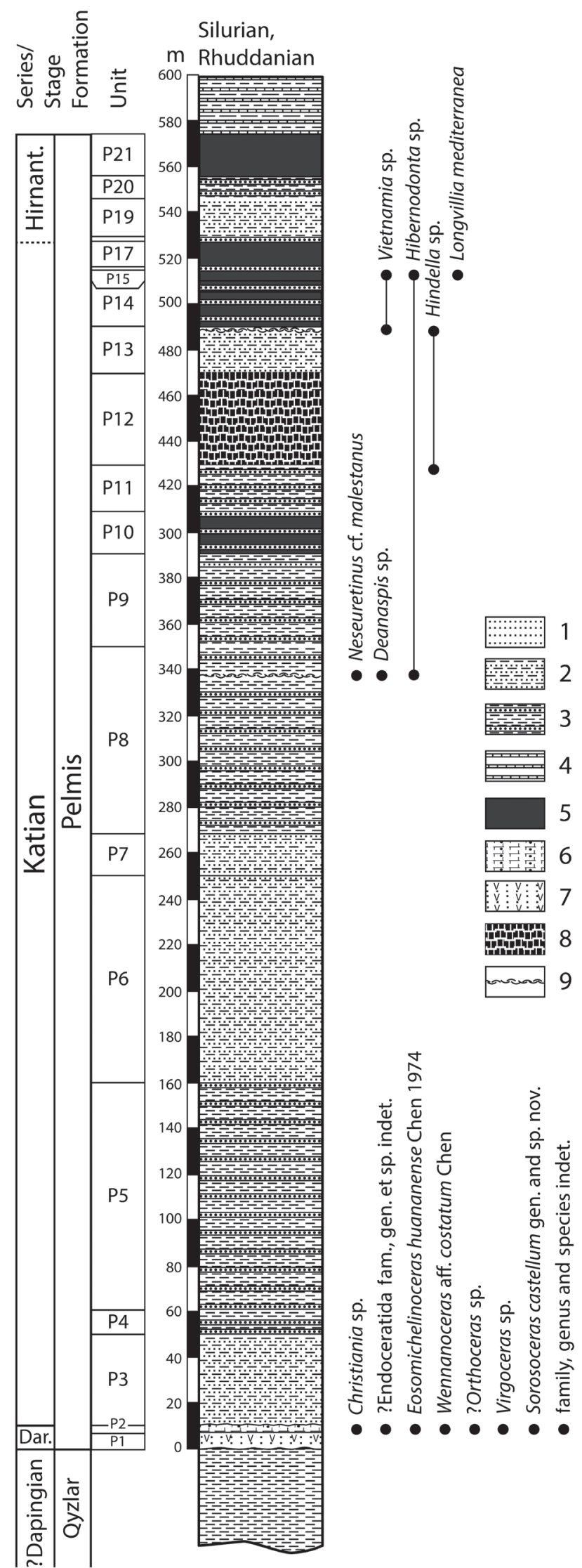


to have been Middle Ordovician in age by Evans (in Evans et al. 2013) on the basis of Chen's statement (Chen 1984, p. 468). The genus has been reported from the Sandbian and early Katian horizons in the Baoto Formation and lithostratigraphical equivalents (Wang 1981, Chen \& Zou 1984) but has also been reported from the Darriwilian of the Precordillera of Argentina (Kröger et al. 2007), the Aserian of Öland (King 1999), the Darriwilian of the Anarak Region, Central Iran (Popov et al. 2015). In those forms ascribed to Eosomichelinoceras from horizons of Darriwilian age, the siphuncle is less marginal in position, as is the case with E. submedius sp. nov., described below. Wennanoceras costatum Chen, 1976 the type species of Wennanoceras Chen, 1976, was first recorded from the Darriwillian, Majiagou Formation of northern China (Chen 1976). Several other species in addition to W. costatum were reported from the Darriwilian, Jigunsan Formation of South Korea (Yun 2011). Chen (1984) described $W$. zixangense Chen from the Jiaqu Formation of Southern Xizang, indicating that the genus ranges upwards into the early Katian. In Iran, a single specimen of Wennanoceras, possibly affiliated to $W$. costatum or $W$. zixangense was reported from the Darriwilian, Chahgonbad Formation of the Anarak Region of Central Iran (Evans in Popov et al. 2015).

Although no body chambers are preserved, so that the key diagnostic features of Orthoceras Bruguière, 1789 cannot be demonstrated, the similarity of the internal morphology of the specimens described below to that of Orthoceratites regularis Schlotheim, 1820, is such that they are considered most likely to belong in Orthoceras. Species attributed to Orthoceras on the basis of the morphology of the body-chamber have been reported from the Lasnamägian and Uhakuan stages of the Baltic region (Dzik 1984, Kröger 2004), and from the Kukrusian Stage in the case of $O$. scabridum Angelin, 1880 in Angelin \& Lindström (1880) (Kröger 2004).

Since the type species of Virgoceras Flower, 1939 is Silurian in age, and Archigeisonoceras Chen, 1984 may be a junior synonym of Virgoceras (Evans et al. 2013), the presence of Virgoceras in this assemblage may not be particularly diagnostic of age. However, the resemblance of these specimens to ?Virgoceras sp. A from the Shirgesht Formation of the Derenjal Mountains (Evans et al. 2013) may support a Darriwilian age for the base of the Pelmis Formation. Evans (in Evans et al. 2013) noted the similarity and possible close relationship of ?Virgoceras sp. A to taxa assigned to Archigeisonoceras by Kröger (2004) from Volkhovian, Kundan, Aserian and Lasnamägian horizons on Öland (Sweden).

Sorosoceras gen. nov. may be closely related to Kinnekulloceras Kröger, 2004. The type species of Kinnekulloceras, Orthoceras kinnekullense Foord, 1887 came from Kinnekulle in Västergötland (Sweden) and was considered by King (1990) to have originated from the Holen Limestone Formation and was therefore Kundan (and probably early Valastean) in age. King (1990) noted that the range of Kinnekulloceras may extend into the Lasnamägian.

Individually, none of the taxa comprising the cephalopod assemblage unequivocally constrain the age of unit P2 of the Pelmis Formation to the Darriwilian. Taken together, however, the assemblage shows similarities to other Iranian Darriwilian cephalopod assemblages from Anarak (Popov et al. 2015), the Derenjal Mountains and Eastern Alborz (Evans et al. 2013). The assemblage is also shows affinities with Baltic and Chinese Darriwilian faunas, although the diversity is much depleted by comparison, particularly in the lack of lituitids, oncocerids and actinocerids.

The presence of Christiania sp. in the oolitic ironstones of the type section suggests that the age of the base of the Pelmis Formation is probably not older than Darriwilian. The oolitic ironstones may be considered a time specific lithofacies of the Darriwilian across northern Iran (Ghobadi Pour et al. 2011, Zadeh et al. 2017). The biostratigraphy of the Pelmis Formation is mainly based on palynomorphs. A complete succession of chitinozoan biozones ranging from the mid Katian Armoricochitina nigerica Biozone to the upper Hirnantian Spinachitina oulebsiri Biozone are recognised (Ghavidel-Syooki 2017a, Ghavidel-Syooki \& Borji 2018). The Katian brachiopods Hibernodonta sp., Hindella sp., Longvillia mediterranea Havlíček, 1981 and trilobites Deanaspis sp., Neseuretinus aff. malestanus (Wolfart, 1970), and Vietnamia sp. occur sporadically in the upper part of the formation (Fig. 3).

Boundaries. - In the type area of the Kalat valley, eastern Saluk Mountains the Pelmis Formation rests disconformably on presumed Middle Ordovician (Dapingian) siltstones. The upper boundary is also disconformable with the Qarebil Formation (Silurian, Llandovery to Wenlock), which contains the Aeronian Stegocornu brachiopod association (Hairapetian et al. 2017), which occurs together with the cephalopod assemblage described by Evans et al. (2015).

Depositional environments and lithofacies. - The Pelmis Formation was deposited in shallow marine environments mainly within the shoreface zone, but grading into deeper, offshore environments within the Ancyrochitina merga Biozone at the Pelmis section. Depth increase was probably due to tectonically induced subsidence prior to the major episode of basaltic extrusive volcanism.

The middle portion of the Pelmis Formation in the Navia Inlier was interpreted by Bayet-Goll \& Carvalho (2016) as a tidally influenced deltaic siliciclastic succession and consists of facies' associations characteristic of 
Table 1. Lithostratigraphical log of the succession of the Pelmis Formation at the type section on the eastern side of the Kalat river valley.

\begin{tabular}{|c|c|c|}
\hline Unit & Description & $\begin{array}{l}\text { Maximum } \\
\text { thickness (m) }\end{array}$ \\
\hline $\mathrm{P} 21$ & Olive green argillites. & 20.0 \\
\hline $\mathrm{P} 20$ & $\begin{array}{l}\text { Grey siltstone with subsidiary beds of medium grained sandstone, up to } 13.5 \mathrm{~m} \text { thick; a lower bed of sandstone } c \text {. } \\
0.4 \mathrm{~m} \text { thick with abundant trace fossils. }\end{array}$ & 14.0 \\
\hline P19 & Laminated siltstone and sandstone intercalations. & 18.5 \\
\hline $\mathrm{P} 18$ & Grey, bedded silty sandstone, c. $0.3 \mathrm{~m}$ thick, with individual beds $3-7 \mathrm{~cm}$ thick. & 0.3 \\
\hline $\mathrm{P} 17$ & Dark grey to grey argillites. & 12.5 \\
\hline P16 & Bedded green sandstones with numerous bioclasts. & 0.5 \\
\hline P15 & Dark grey argillite, with long crinoid stems preserved on a few bedding surfaces. & 5.0 \\
\hline P14 & $\begin{array}{l}\text { Grey argillites with subsidiary beds of horizontally laminated sandstones with loose concentrations of disarticulated } \\
\text { brachiopod shells. }\end{array}$ & 19.0 \\
\hline P13 & $\begin{array}{l}\text { Greenish grey sandstone and siltstone intercalations, with numerous trace fossils in the lower } 6 \mathrm{~m} \text { and a brachiopod } \\
\text { shell bed c. } 0.3 \mathrm{~m} \text { thick at the top of the unit. }\end{array}$ & 21.0 \\
\hline $\mathrm{P} 12$ & Basaltic volcanic rocks. & 40.0 \\
\hline P11 & Greenish grey siltstone and subsidiary intercalations. & 20.0 \\
\hline $\mathrm{P} 10$ & $\begin{array}{l}\text { Dark grey to black argillite and subsidiary coarse to medium grained sandstone intercalations with individual } \\
\text { sandstone beds } 5-10 \mathrm{~cm} \text { thick. }\end{array}$ & 20.0 \\
\hline P9 & Greyish green siltstone and subsidiary coarse-grained sandstone intercalations. & 40.0 \\
\hline P8 & $\begin{array}{l}\text { Greenish-grey siltstones with subsidiary beds of sandstone } 5-20 \mathrm{~cm} \text { thick and a } 20 \mathrm{~cm} \text { thick shell bed with } \\
\text { disarticulated shells of brachiopods and bivalves. }\end{array}$ & 83.0 \\
\hline P7 & $\begin{array}{l}\text { Intercalated siltstones and sandstones, with a bed of impure bioclastic limestone up to } 0.1 \mathrm{~m} \text { thick, containing } \\
\text { echinoderm ossicles and brachiopod shell fragments. }\end{array}$ & 17.0 \\
\hline P6 & $\begin{array}{l}\text { Greenish-grey siltstone and coarse to medium grained micaceous sandstone intercalations with individual beds } \\
0.2-0.3 \mathrm{~m} \text { thick and trace fossils on the bedding surfaces. }\end{array}$ & 90.0 \\
\hline P5 & Green and grey siltstone with subsidiary beds of coarse grained sandstone varying from 5 to $20 \mathrm{~cm}$ thick. & 98.0 \\
\hline P4 & Green siltstone with thin subsidiary sandstone beds and $1 \mathrm{~m}$ of greenish-grey quartzose sandstone at the base. & 11.0 \\
\hline P3 & Intercalated green micaceous siltstone and coarse-grained quartzose sandstone, with cross and planar lamination. & 39.0 \\
\hline $\mathrm{P} 2$ & $\begin{array}{l}\text { Two beds of oolitic ironstone divided by a limestone bed with abundant cephalopods and brachiopods about } 1.5 \mathrm{~m} \\
\text { thick. }\end{array}$ & 5.0 \\
\hline $\mathrm{P} 1$ & Greenish-grey andesitic-basaltic tuff. & 9.0 \\
\hline
\end{tabular}

lower distributary channels, delta front and prodelta environments. This part of the succession contains abundant trace fossils characteristic of the Cruziana and Skolithos ichnofacies.

Proximity to the land area can be inferred from the abundance of cryptospores, which represent the most common component in the palynomorph samples through the Upper Ordovician succession (Ghavidel-Syooki 2017b).

Remarks. - Previously, the Ordovician deposits here included to the Pelmis Formation were usually considered to represent the local development of the Ghelli Formation (Bayet-Goll \& Carvalho 2016, Ghavidel-Syooki 2017a, Ghavidel-Syooki \& Borji 2018 etc.).

\section{Source of the cephalopod assemblage}

The orthoconic cephalopod fauna described in this study was recovered from the bed of limestone sandwiched between beds of oolitic ironstone comprising Unit P2 of the lowermost portion of the Pelmis Formation (Tab. 1, Fig. 3). The location from which the material originated is the same location as the base of the stratotype section of the Pelmis Formation.

It is possible that the cephalopod limestone resting on the Volcanic Member of the Ghelli Formation north of Ghelli village reported by Ghavidel-Syooki and Winchester-Seeto (2002), is synchronous with the oolitic ironstone Unit P2 of the Pelmis Formation, but cephalopods from Ghelli were not available for the present study. 


\section{Preservation of cephalopods}

Description. - The bulk of specimens consist of fragments representing the internal molds of phragmocones and bodychambers. In the majority of specimens, the original conch walls are missing having been worn away or exfoliated. Very rarely, small patches of the conch wall may be preserved. Many of the conch fragments are a partially coated with a thin skin of tufa. The surfaces of a large number of specimens show areas, of varying extent, that are covered with small pits $(0.05-0.2 \mathrm{~mm}$ in diameter $)$ and coated with a thin skin of iron oxides and/or druzy silica, interpreted here as desert varnish. Where present, the tufa invariably coats the desert varnish.

The conch fragments forming the sample from Unit P2 vary in diameter, length (Fig. 4A), and in the case of phragmocones, the number of camerae preserved (Fig. 4A, B). As this material was collected ex-situ, and given the presence of tufa and desert varnish combined with the degree of wear of the conch fragments, it is probable that it represents the products of modern weathering over a long interval. The sample consists of pieces of phragmocone comprised of $1-12$ camerae that range from $5-20 \mathrm{~mm}$ in diameter and $5-45 \mathrm{~mm}$ in length. Although the numbers of individuals in each class declines slightly with increasing numbers of camerae, frequencies only drop off sharply above six camerae.

Apart from the general lack of the conch walls, the phragmocones and body-chambers exhibit varying degrees of weathering or wear. This ranges from fresh, clean surfaces lacking desert varnish, to specimens exhibiting a slight widening and deepening at the sutures, through to individuals with deeply incised sutures exposing large areas of the septal surfaces. In both of the latter cases the presence of a coating of desert varnish suggests that the erosion or corrosion of the conch took place prior to the deposition of the varnish. In addition, some of the more deeply incised sutures may also exhibit a coating of sheared mudstone that partially covers septal surfaces.

All the cephalopods are preserved in maroon-coloured micritic carbonates or carbonate mudstones, and may be infilled with this sediment, sparite, or a combination of the two. Where specimens have been sectioned, generally, those filled with mudstone have intact septa but lack
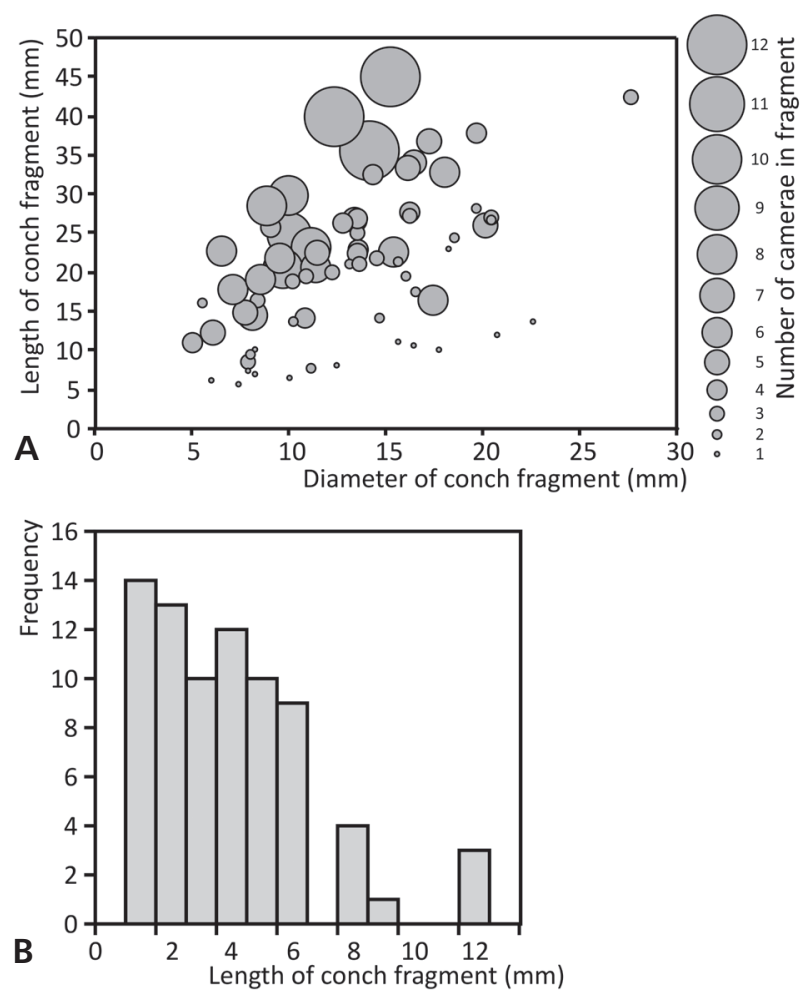

Figure 4. Dimensions of cephalopod conch fragments in the Pelmis Formation sample. $•$ A - length of conch fragments plotted against diameter and number of camerae in each fragment. $-\mathrm{B}$ - frequency distribution of number of camera in each conch fragment.

connecting rings (Fig. 5A, L). The connecting rings remain intact or partially intact in a handful of specimens. In such specimens the septa, walls of the camerae and the connecting rings are generally coated with a layer of isopachous sparite (Fig. 5E, N). In some individuals the lumen of the siphuncle is also filled with isopachous sparite (Fig. $5 \mathrm{H}, \mathrm{M}$ ), but in others only micrite is present (Fig. 5B). The remaining volume in the camerae of these particular specimens either consists of a coarse amorphous sparite (Fig. 5E), or micrite (Fig. 5M), or a combination of both (Fig. 5H).

Septa remain intact in $85 \%$ (101) of the specimens. Of those specimens where the septa are broken or missing (18), all except two are filled with micrite, and the remains of the septa either entirely missing, floating in the matrix,

Figure 5. Cephalopods from the Pelmis Formation. $・$ A - Wennanoceras aff. costatum Chen, 1976; longitudinal transverse section showing location of septal foraminae and form of septal necks; NMW 2019.6G.30; scale bar $=5 \mathrm{~mm}$. $・$ B-D - ?Orthoceras sp.; B - longitudinal, near dorsoventral section though apical portion of phragmocone showing thinly developed mural and episeptal cameral deposits, NMW 2019.6G.84, scale bar $=5 \mathrm{~mm}$; $\mathrm{C}$ - longitudinal section in dorsoventral plane showing partially intact siphuncle and incipient episeptal cameral deposits ventrally (left), NMW 2019.6G.124, scale bar $=5 \mathrm{~mm}$; D - dorsoventral sagittal section showing location of siphuncle and the presence of incipient episeptal cameral deposits, NMW 2019.6G.128, scale bar $=5 \mathrm{~mm}$. E E, I - Eosomichelinoceras submedius sp. nov., NMW 2019.6G.68; E - dorsoventral sagittal section showing siphuncle, scale bar $=5 \mathrm{~mm}$; I - detail of siphuncle with septal necks and connecting ring, scale bar $=2 \mathrm{~mm}$. $\bullet \mathrm{G}, \mathrm{K}, \mathrm{L}-$ ?Virgoceras sp.; G - detail of septal necks in dorsoventral section, NMW 2019.6G.93, scale bar $=2 \mathrm{~mm} ; \mathrm{K}-$ dorsoventral section with heavily altered and massive episeptal deposits on the venter and thin episeptal deposits developed on the dorsal side of the septum, NMW 2019.6G.26, scale bar $=5 \mathrm{~mm}$; L - dorsoventral sagittal 

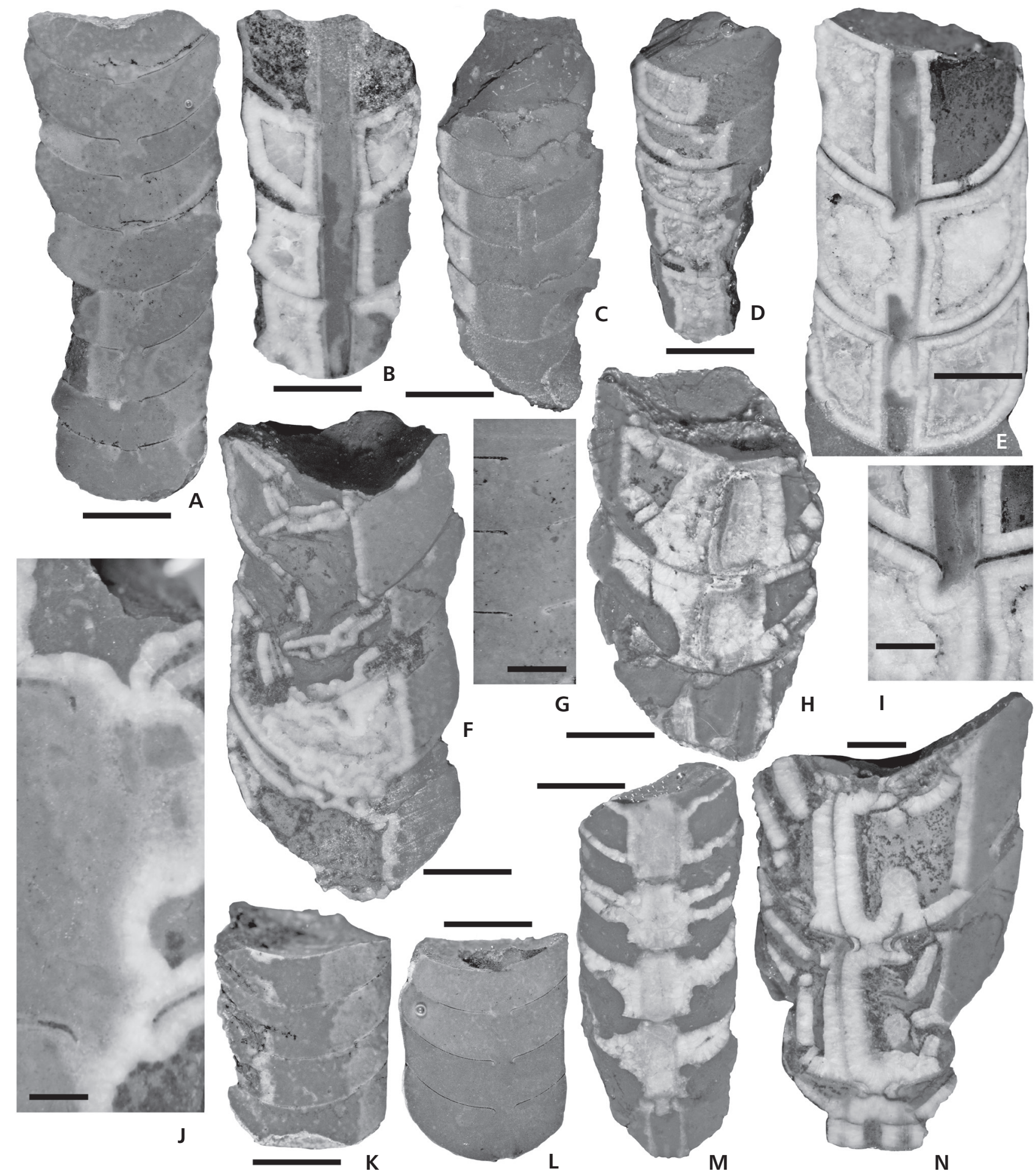

J

$\mathrm{K}$
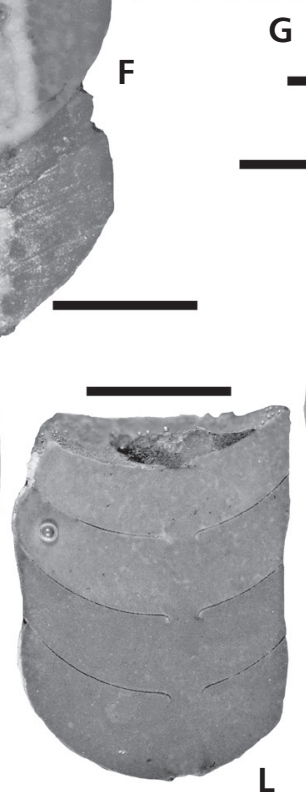

$\mathbf{F}$
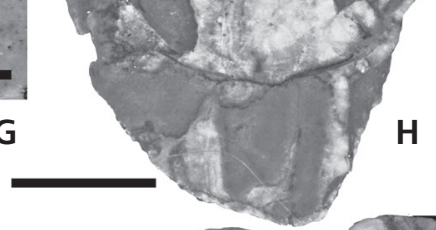

H
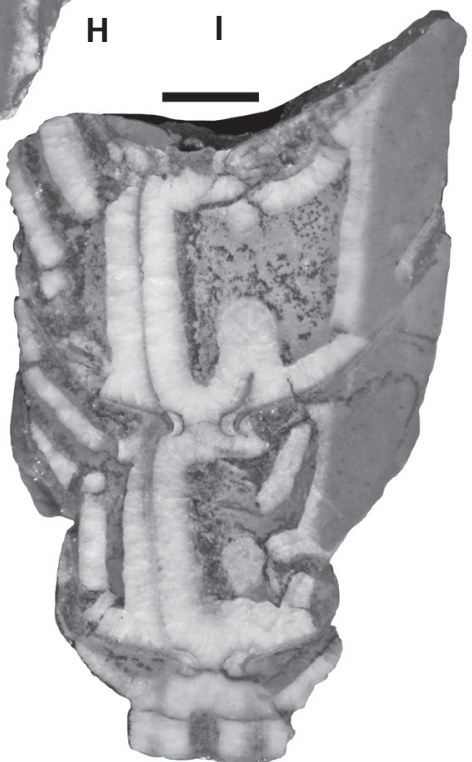

N

section through phragmocone, NMW 2019.6G.88, scale bar $=5 \mathrm{~mm} . \cdot \mathrm{F}, \mathrm{H}, \mathrm{J}, \mathrm{M}, \mathrm{N}-$ Sorosoceras castellum gen. et sp. nov.; F - partially crushed and fractured phragmocone with incipient episeptal cameral deposits, and with annuli developed at the septal necks adorad of the cameral deposits, NMW 2019.6G.35, scale bar $=5 \mathrm{~mm} ; \mathrm{H}$ - slightly off-plane dorsoventral section through a phragmocone showing with intact connecting rings and showing annuli developed at the septal necks with parietal deposits extending adorally, mainly onto the ventral surfaces of the connecting rings, well-developed mural and episeptal cameral deposits present ventrally and replaced, NMW 2019.6G.126, scale bar $=5 \mathrm{~mm}$; J - detail of septal necks in mature portion of phragmocone, NMW 2019.6G.2, scale bar $=2 \mathrm{~mm}$; M - lateral section through phragmocone showing the outlines of replaced episeptal, mural and hyposeptal cameral deposits, NMW 2019.6G.120, scale bar $=5 \mathrm{~mm} ; \mathrm{N}$ - section through partially crushed phragmocone with partially intact connecting rings, suborthochanitic septal necks showing annuli attached to them, NMW 2019.6G.125, scale bar $=5 \mathrm{~mm}$. 
or are piled up within the empty phragmocone. The two exceptions (Fig. 5F, N), are partly filled with isopachous and coarse sparite fills. In these individuals, the isopachous sparite coating the septa, together with the septa, are fractured and float in the micritic matrix.

In some specimens, the camerae contain variable quantities of micrite coated by a layer of isopachous sparite, sometimes with a core of coarse sparite and/or micrite. The floors of such cavities, where they occur in successive camerae may all have a similar orientation (Fig. 5C, D), suggesting that they represent geopetal fills.

Bioclasts are present in the infilling matrix of $60 \%$ of the specimens. They consist mainly of ostracods and pelmatozoan debris. In body-chambers and many of the phragmocones where the septa are broken, the bioclasts include coarser fragments in addition to the ostracod and pelmatozoan debris. This includes trilobite debris, highspired gastropods and cystoid plates. No clear evidence of bioturbation has been observed in any of the specimens.

An epifauna has only been observed on nine specimens (7.5\%). This number may be an underestimate because of the obscuring a coating of tufa on some specimens. Where seen, however, the extent of encrustation is quite limited, and there is rarely more than one individual attached to a conch. The epifauna consists bryozoans, but includes an inarticulate brachiopod, and on one body-chamber (Fig. 6), the calyx of a sphaeronitid cystoid.

In several specimens part of the micritic fill and the cameral deposits appear to have been altered (Fig. 5B, F, $\mathrm{H}, \mathrm{K}, \mathrm{M}, \mathrm{N})$. Parts of the micritic fill are darker and more granular, while the cameral deposits lack their original fabric and are of a colour similar to the altered matrix, being only possible to distinguish from the matrix through their overall shape. Both thealtered cameraldepositsand thematrix contain numerous dark inclusions that may be faintly dendritic and possibly consist of iron oxides and hydroxides.

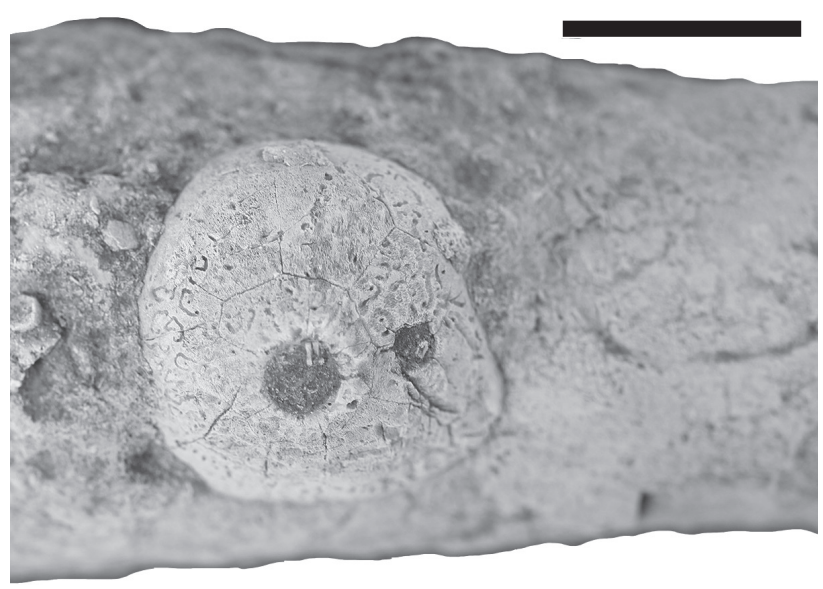

Figure 6. Sphaeronitid blastozoan attached to the body-chamber of an indeterminate orthocerid; NM 2019.6G.60; scale bar $=10 \mathrm{~mm}$.
Interpretation. - Most of the phragmocones contain sediment similar to the surrounding matrix and lack connecting rings. This suggests that the empty conchs remained on the sea floor or were repeatedly redeposited/ transported for a sufficient interval for the organic components of the connecting ring to decay, facilitating the passage of sediment and the smaller bioclasts into the camerae. This process may have been enhanced by the breakage of the phragmocone into segments, as well as the puncturing of the conch wall; permitting a current to flow through the phragmocone (Seilacher 1969).

The minority of the conchs contains a sparite fill that may have preceded and/or followed the introduction of some micritic fill. This reflects the early burial of the conch; effectively removing it from the influences of current activity and mobile sediment and facilitating the precipitation of sparite onto the surfaces within the camerae, including the remains of the connecting rings, which were thereby permanently preserved. The fracturing of the septa, connecting rings and isopachous coatings seen in some individuals (Fig. 5F, N) may indicate the loading and partial failure of the conch during burial. The post-failure fill in such specimens is distinct from earlier micritic fills in that it is a darker shade and contains even darker inclusions. This fill is interpreted as having been injected into the phragmocone through the fractures generated by the failure of the conch wall and septa. The inclusions may reflect the high porosity of the injected sediment, leaving space for the later development of inclusions and facilitating the alteration of the micritic fill and the cameral deposits.

In those conchs that contain geopetal fills, the angles that the fills make with the matrix indicate that most of the phragmocones came to rest and were buried with the conch axis more-or-less parallel to the substrate.

The general lack of evidence of an epifauna on the conchs could reflect their rapid burial. But this would be in contradiction to the observations related to the loss of the connecting rings and the sediment fill. It is more likely that the lack of an epifauna is the consequence of the loss of the conch wall. Several specimens show deeply incised sutures with exposed septal surfaces that are coated with matrix. The presence of the matrix coating worn surfaces suggests that many of the conchs had been exhumed at least once before their final burial, and the wear that they were subject to once exposed, would have resulted in the loss of the conch wall and the incisions at the sutures.

The range of states of preservation of the cephalopods from the limestone unit of Bed P2 suggests that the assemblage is time-averaged and contains a mixture of relatively fresh specimens, ranging through to individuals where the infilling matrix had been lithified and may then have been subjected to several cycles of exhumation and reburial. 


\section{Conclusions}

The composition of the cephalopod fauna present in the oolitic ironstones at the base of the Pelmis Formation indicates that this horizon is most likely to be Darriwilian in age and contains genera common to both to Baltica as well as South and North China, although at a small fraction of their diversities. When compared with other Darriwilian cephalopod assemblages from Iran (Evans et al. 2013, Bogolepova et al. 2014, Popov et al. 2015), there are relatively few elements common to any two assemblages (comprising Dideroceras, Eosomichelinoceras, Sactorthoceras, Wennanoceras, Virgoceras), these taxa may reflect an endemic mid to high latitude element of these faunas. Whether similar cores of taxa exist in coeval assemblages from Perunica and Armorica is yet to be demonstrated, but it is clear that other taxa such as Bathmoceras Barrande, 1867 are a frequent component of the latter assemblages. With the exception of the Abustu Formation (Bogolepova et al. 2014), those taxa that only occur in one of the assemblages are in the majority. This may suggest that a large component of the cephalopod fauna reflects ephemeral populations arising from short-lived migrations of Baltic and Chinese taxa onto this part of the Gondwana margin.

It is notable that the Pelmis Formation cephalopod assemblage, like those of the Shirgesht and Lashkarak formations (Evans et al. 2013) as well as the Chahgonbad Formation (Popov et al. 2015) occur as concentrations, either associated with oolitic ironstones at the base of the formation, or in thin sandy carbonates at the base of succession. Similar horizons containing locally abundant cephalopods occur at the base of a number of formations in the proximal parts of the Prague Basin (Štěpán Manda, personal communication 2020). The horizons in the Prague Basin require further investigation, but together with those observed in Iran, may indicate that these accumulations represent reworked material deposited at the base of transgressive sequences. As such, the cephalopod assemblages may represent a time-averaged fauna containing both endemic elements and more exotic elements representing ephemeral migrations that can longer be to distinguished from the endemic assemblage.

\section{Systematic Palaeontology}

Order Endoceratida Teichert, 1933

\section{?Endoceratida fam., gen. et sp. indet.}

Figure 7A-C

Material. - Single specimen NMW2019.6G.47. The specimen consists of the mould of a sediment-filled siphuncle.
Description. - The siphuncle fragment is $47 \mathrm{~mm}$ long and decreases in its dorsoventral diameter from 17.2 apically to $15.4 \mathrm{~mm}$ adorally giving a rate of contraction of $2^{\circ}$. The respective lateral diameters are 19.2 and $17.3 \mathrm{~mm}$ giving a depressed cross-secton with a ratio of 0.89 . The ventral side of the siphuncle is nearly flat, indicating that it was incontact with the wall of the phragmocone and suggesting that the diameter of the phragmocone was substantially greater than that of the siphuncle. The septal foraminae are about $10 \mathrm{~mm}$ apart, but the surface of the siphuncle is too poorly preserved to determine whether the septal necks were holochoanitic or macrochoanitic.

Remarks. - The lack of endosiphuncular deposits in this specimen means that it is not certain that this specimen can be assigned to the Endocerida, while that lack of evidence regarding the length of the septal necks would also make it impossible to assign it to a family or genus. This specimen is only included here as it is the only example of a probable endocerid in the assemblage. The adoral decrease in the diameter of the siphuncle is noteworthy.

Subclass Orthoceratoidea McCoy, 1844

Order Dissidoceratida Zhuravleva, 1964

Suborder Dissidoceratina Zhuravleva, 1964

Family Baltoceratidae Kobayashi, 1935

\section{Eosomichelinoceras Chen, 1974}

Type species. - Eosomichelinoceras huananense Chen 1974.

Remarks. - See Popov et al. (2015) for discussion of the status of the type species.

Eosomichelinoceras submedius sp. nov.

Figures 5E, I; 7F, G, H, M, N, P

2014 Eosomichelinoceras sp. - Bogolepova et al., p. 35, fig. $3 \mathrm{a}-\mathrm{c}$.

Types. - Syntypes NMW2019.6G.68, 91, 92, 116, 121.

Type horizon and locality. - Limestone at the base of the stratotype section of the Pelmis Formation (Unit P2). Kalat river valley; eastern part of the Saluk area, $37^{\circ} 13^{\prime} 49^{\prime \prime} \mathrm{N}$, $57^{\circ} 23^{\prime} 3^{\prime \prime} \mathrm{E}$, Iran.

Additional material. - Museum of Evolution, Uppsala, Sweden PMU 27274-6 from the Abastu Formation, Abarsaj section, near Shahrood, north-eastern Iran (see Bogolepova et al. 2014, p. 34, figs 1, 2).

Etymology. - Latin medius (central). Referring to the eccentric position of the siphuncle. 
Diagnosis. - Eosomichelinoceras with moderately deep camerae (50-60\% of conch diameter), and a tubular, eccentrically located siphuncle, lying closer to the conch axis than seen in other members of the genus.

Description. - Slowly expanding conchs $\left(\right.$ mean $=5^{\circ} 48^{\prime}$; standard deviation $=1.29 ; \mathrm{N}=5$ ) reaching at least $27 \mathrm{~mm}$ in diameter. The camerae are moderately deep (50-60\% of conch diameter) throughout the length of the phragmocone. The septal depth is $28 \%$ of the conch diameter. The diameter of the siphuncle ranges from $8.5-$ $14.5 \%($ mean $=11.8 \%$; standard deviation $=2.3 ; \mathrm{N}=5)$ of the phragmocone diameter, but shows no trend in relative diameter with growth of the conch. The centre of the siphuncle lies at about $40 \%$ of the distance across the siphuncle diameter. The structure of the siphuncle is visible in NMW2019.6G.68, where the septal necks are short and orthochoanitic and slightly longer on the side of the siphuncle closest to the phragmocone wall (?ventral). The connecting rings are thin $(0.1 \mathrm{~mm})$ and tubular, although very weakly constricted at the septal necks (Fig. 5E, I). No endosiphuncular of cameral deposits are evident in any of the specimens studied.

The conch sculpture may be seen in NMW2019.6G.116 (Fig. $7 \mathrm{H}, \mathrm{N}$ ). In this specimen the conch sculpture is visible on one surface, although the original shell has largely gone. The sculpture comprises low, rounded lirae, about $0.7 \mathrm{~mm}$ in width, separated by broad flat interspaces up to $0.45 \mathrm{~mm}$ wide. In some places the lirae are wider $(0.12 \mathrm{~mm})$ and more densely spaced (8 lirae per $\mathrm{mm}$ ).

Remarks. - Eosomichelinoceras submedius differs from E. huananense in that the siphuncle is more distant from the conch wall and the camerae are shallower. E. tortum Angelin, 1880 in Angelin \& Lindström (1880), from the Aserian Stage of Öland, Sweden, (see King 1999, fig. $8 \mathrm{a}, \mathrm{b}$ ) is similar to E. huananense. Eosomichelinoceras baldisii Kröger in Kröger et al. (2007) from the Middle Ordovician portion of the San Juan Formation of San Juan Province, Argentina differs from E. huananense in its shallower camerae, broader siphuncle with more inflated connecting rings, and the greater relative distance of the siphuncle from the conch wall. E. baldisii differs from E. submedius in the shallower camerae and the inflation of the connecting rings, although the relative position of the siphuncle is similar. The single specimen of Eosomichelinoceras described from the Middle Ordovician Chahgonbad Formation of the Anarak region in central Iran (Evans in Popov et al. 2015) shares the relative location and diameter of the siphuncle with the type species, but possesses much shallower camerae. Although Bogolepova et al. (2014) decribed the specimens from Abarsej as having a siphuncle that lies at a position 0.27 of the way across the phragmocone diameter, measurements taken from their images (Bogolepova et al. 2014, fig. 3a-c), indicates that the centre of the siphuncle lies at about $40 \%$ of the distance across the phragmocone, and although the camerae are slightly shallower, they appear so similar to the Ghelli Formation specimens that they are included in E. submedius here.

Order Orthoceratida Kuhn, 1940

Family Sactorthoceratidae Flower, 1946

\section{Genus Wennanoceras Chen, 1976}

Type species. - Wennanoceras costatum Chen, 1976, p. 67, pl. 2, fig. 1. From the Darriwilian, Majiagou Formation of Shandong, China.

Remarks. - Yun (2011) assigned several taxa to the genus where the number of camerae present within the distance of a single annulation exceeded that of the type species. In noting that the presence of fine concentric growth lines between the annulations in Wennanoceras sp. A, were an exception for the genus, he also implied that Wennanoceras is free of any kind of sculpture on the surface of the conch. In relation to the presence of the growth lines in $W$. sp. A, Yun (2011) alluded to its similarity in this respect to Orthoceras undulostriatum Hall, 1847, the type species of Striatocycloceras Kröger \& Isakar, 2006. This specimen may also bear some similarity to Striatocycloceras in the deflection of the annulations from dorsum to venter. Based on the Late Ordovician material

Figure 7. Cephalopods from the Pelmis Formation. • A-C - ?Endocerida fam., gen. et sp. indet. A; A - lateral view of siphuncle (venter on right); B - ventral view; C - dorsal view, NMW 2019.6G.47, scale bar $=10 \mathrm{~mm}$. $・$ D, E - Wennanoceras aff. costatum Chen, 1976; D - (?)dorsal view of phragmocone; E - lateral view of phragmocone, NMW 2019.6G.30, scale bar $=10 \mathrm{~mm}$. $・ \mathrm{~F}, \mathrm{G}, \mathrm{H}, \mathrm{M}, \mathrm{N}, \mathrm{P}-$ Eosomichelinoceras submedius $\mathrm{sp}$. nov.; F, G - dorsal and ventral views of external mould of phragmocone, NMW 2019.6G.68, scale bar = 10 mm; M, P - apical and dorsal views of phragmocone, scale bar $=10 \mathrm{~mm} ; \mathrm{H}$ - detail of shell sculpture, NMW 2019.6G.116, scale bar $=2 \mathrm{~mm} ; \mathrm{N}$ - phragmocone showing shell sculpture, scale $\mathrm{bar}=10 \mathrm{~mm}$. $\bullet \mathrm{I}-\mathrm{L}, \mathrm{O}, \mathrm{Q}, \mathrm{R}, \mathrm{U}-\mathrm{Y}-$ ? Orthoceras sp.; I - ventral surface internal mold of phragmocone showing molds of mammilate cameral deposits, NMW 2019.6G.121, scale bar $=10 \mathrm{~mm}$; J - ventral view of internal mould of phragmocone with concave wall of camerae apically where mural cameral deposits were originally present, NMW 2019.6G.82, scale bar $=5 \mathrm{~mm} ; \mathrm{K}, \mathrm{L}-$ apical and lateral views of internal mold of phragmocone, the latter with concave walls indicating the original presence of mural cameral deposits, NMW 2019.6G.84, scale bar $=5 \mathrm{~mm}$; O - portion of phragmocone, NMW 2019.6G.107, scale bar $=5 \mathrm{~mm}$; Q, R - lateral and ventral views of the internal mold of a phragmocone showing partially exfoliated mural cameral deposits on the cameral walls, NMW 2019.6G.107, scale bar $=5 \mathrm{~mm}$; S, T - lateral and ventral views of internal mold of phragmocone showing the molds of mural cameral deposits that become increasingly thick adapically, NMW 2019.6G.118, scale bar $=5 \mathrm{~mm}$; U, V - lateral and ventral views of 

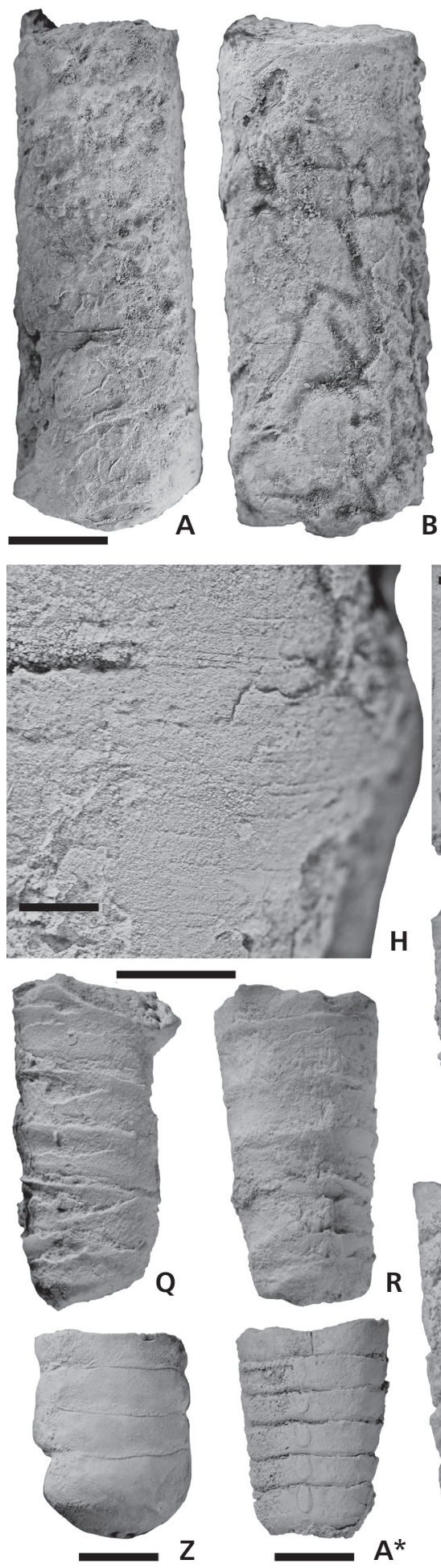
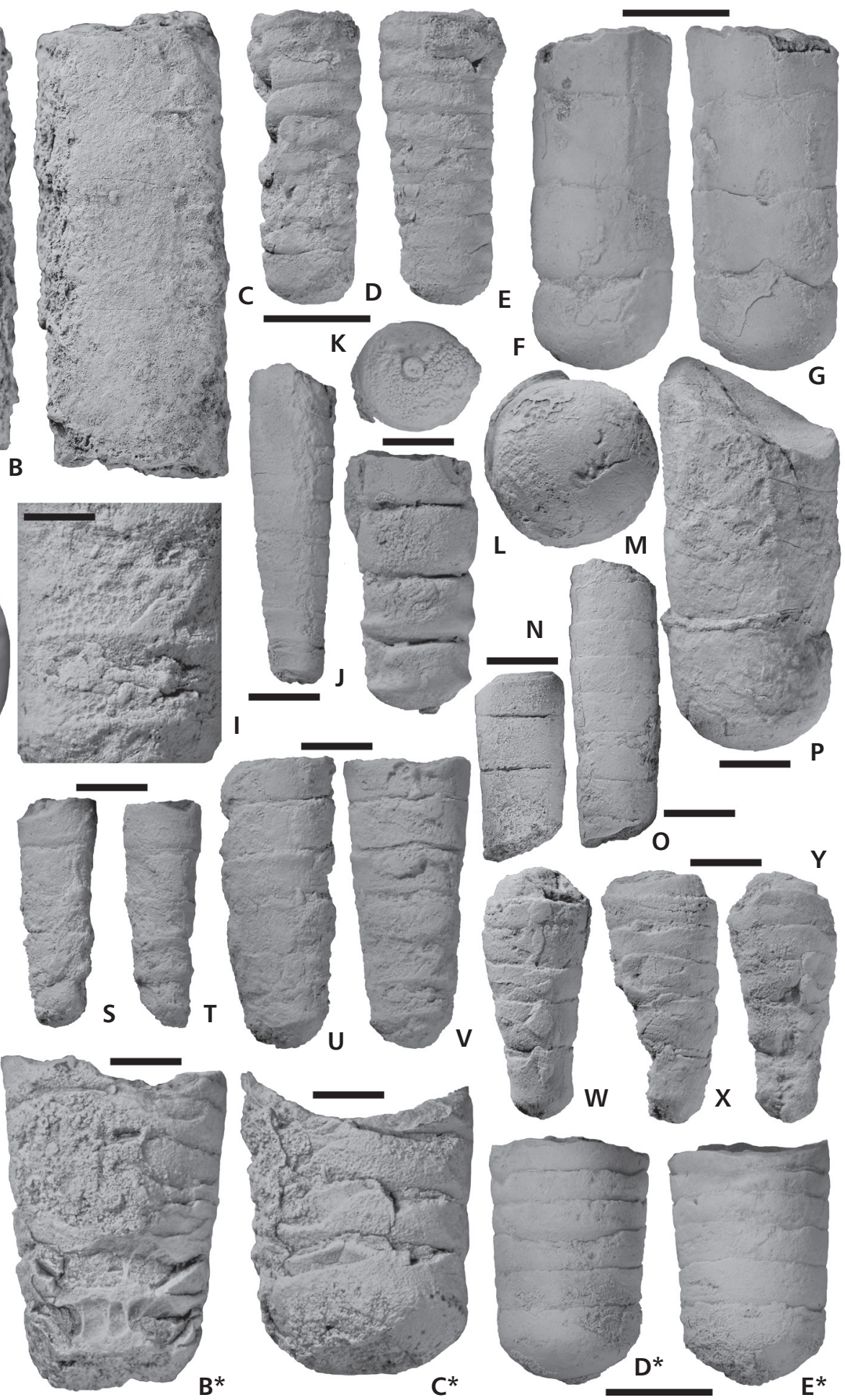

$B^{*}$
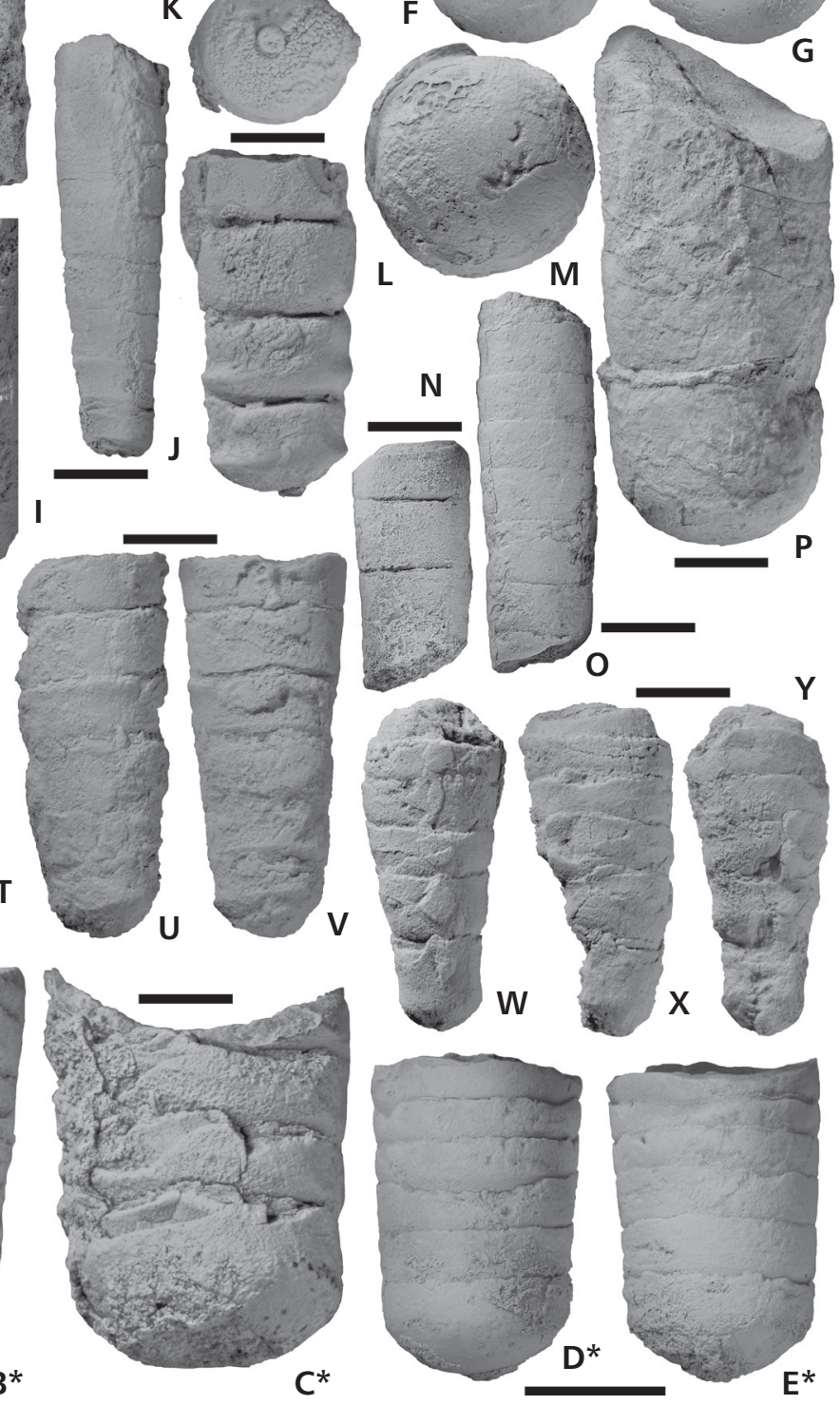

phragmocone showing hollows in the mural surfaces of the camerae where the mural episeptal deposits have exfoliated or worn away, NMW 2019.6G.129, scale bar $=5 \mathrm{~mm}$; W, X, Y - phragmocone, NMW 2019.6G.128, dorsal view (W), lateral (X) showing partially exfoliated mural deposits; ventral (Y) showing partially exfoliated mural deposits and gaps at the septa indicating the presence of thin episeptal deposits, scale bar $=5 \mathrm{~mm}$. $\cdot \mathrm{Z}, \mathrm{A}^{*}-\mathrm{E}^{*}-$ ?Virgoceras sp.; Z - slightly worn internal mould of phragmocone, NMW 2019.6G.88, scale bar = 5 mm; A*, B* - portion of phragmocone, NMW 2019.6G.45, dorsal view (A*) showing septal furrow (scale bar $=5 \mathrm{~mm}$ ), ventral view (B*) showing molds of extensive mural and episeptal cameral deposits at adoral end of fragment (scale bar $=2.5 \mathrm{~mm}$ ); $\mathrm{C}^{*}$ - internal mould of phragmocone showing mold of finely mammilated surface of episeptal deposits, NMW 2019.6G.26, scale bar = 2.5 mm; D*, E* - lateral and ventral views of portion of phragmocone, NMW 2019.6G.4, scale bar $=10 \mathrm{~mm}$. 
assigned to Striatocycloceras (Kröger \& Isakar 2006, Kröger et al. 2011, Kröger 2013), Wennanoceras may be similar internally, but is distinguished both by the lack of a conch sculpture, the much lesser degree of deflection of the annulations, and the lack of sinuosity of the annulations by comparison with Striatocycloceras.

\section{Wennanoceras aff. costatum Chen, 1976}

Figures 5A; 7D, E

\section{Material. - Single specimen NMW2019.6G.30.}

Description. - This specimen consists of a short length of phragmocone $23 \mathrm{~mm}$ long and increasing in diameter from 8.9 to $11.1 \mathrm{~mm}$ giving a rate of expansion of $5^{\circ} 40^{\prime}$. Cameral depth is $26 \%$ that of the phragmocone diameter, with one annulation of the conch in the interval of a camera. The annulations are about $0.16 \mathrm{~mm}$ high and the crests relatively narrow with broad interspaces. The sutures lie at the adoral ends of the interspaces and are straight but slightly oblique to the plane normal to the conch axis. The relative depth of the septa is $30 \%$ that of the phragmocone diameter. The relative diameter of the siphuncle is $11 \%$ that of the phragmocone and the location of its centre, very nearly central. The septal necks are orthochoanitic and $0.4 \mathrm{~mm}$ long (Fig. 5A). No cameral or endosiphuncular deposits are evident. The conch wall is largely missing or corroded so that it is not known whether any kind of shell sculpture was present.

Remarks. - Yun (2011) described several species of Wennanoceras from the Jigunsan Formation of South Korea. These included the type species and several other species that may indicate a wide range of intrageneric variation (Popov et al. 2015). Comparison of the specimen from the Pelmis Formation with those from South Korea indicates that it is closest to $W$. costatum.

Family Orthoceratidae M'Coy, 1844

\section{Orthoceras Bruguière, 1789}

Type species. - Orthoceratites regularis Schlotheim, 1820.

\section{?Orthoceras sp.}

Figures 5B-D; 7I-L, O, Q, R, U-Y

Material. - NMW2019.6G.51, 64, 67, 79, 81, 82, 84, 101, 104, 107, 109, 118, 124, 128, 129.

Description. - The material assigned to this taxon consists entirely of pieces of a phragmocone of a small diameter with expansion rates between $4^{\circ} 29^{\prime}$ and $1^{\circ} 15^{\prime}$ (mean $=$ $\left.3^{\circ} 6^{\prime} ; \mathrm{N}=10\right)$. Cameral depth decreases from $64 \%$ of the phragmocone diameter at a diameter of $3.47 \mathrm{~m}$ to $26.6 \%$ at $8.55 \mathrm{~mm}$ (Fig. 8A). Septal depth as measured from internal moulds ranges from $19.51 \%$ to $31.54 \%$ of the phragmocone diameter (mean $=25.34 \% ; \mathrm{N}=8$ ) but in a transverse section of an intact septum in NMW2019.6G.124 the depth is $29 \%$, suggesting that most of the internal moulds are too weathered to provide accurate measurements of this character.

The septal foramen is central in position or else slightly displaced from the conch axis, lying between $50-48 \%$ across the diameter of the phragmocone (Fig. 8D; mean $=46.2 \% ; \mathrm{N}=6$ ). Within the range of conch diameters measured $(6.2-9.23 \mathrm{~mm})$ there is no clear evidence of change in the position of the septal foramen with ontogeny. The relative diameter of the septal foramen varies from $8.67 \%$ to $13.8 \%$ of the conch diameter (mean $=11.07 \% ; \mathrm{N}=6$ ). As seen in polished sections (Fig. 5B-D), the septal necks are mainly orthochoanitic, but vary from aneuchoanitic to suborthochoanitic. Where orthochoanitic or suborthochoanitic, the septal necks range from $0.2-0.35 \mathrm{~mm}$ in length. The connecting ring is seen in NMW2019.6G.84 (Fig. 5B) and in one segment of NMW2019.6G.124 (Fig. 5C). In both specimens, the connecting rings are tubular but faintly fusiform. The connecting ring undergoes rapid expansion either side of the septal foramen to reach a diameter 1.2 times that of the septal foramen. In NMW2019.6G.124, where the septal foramen is displaced from the conch axis, the profile of the connecting ring is asymmetrical in the dorsoventral plane, with the presumed ventral side being slightly more inflated. The profile of the connecting ring is symmetrical in NMW2019.6G.84, an individual where the septal foramen is aligned with the conch axis. The connecting rings appear to be about $0.08 \mathrm{~mm}$ in thickness in both specimens.

None of the specimens sectioned show any evidence for the presence of endosiphuncular deposits. Cameral deposits are evident in several specimens (NMW2019.6G.81, 84, 107, 118, 124, 128, 129) and show some variation in their development. Very thin episeptal deposits extend about half the distance between the conch wall and the septal foramen on one side (?ventral) of the conch in NMW2019.6G.129 (8.55 mm in diameter). In this specimen, the degree of development of the cameral deposits does not increase consistently in an apical direction, possibly reflecting their incipient development in this particular specimen. NMW2019.6G.128 (Fig. 5D), is of a similar diameter and displays episeptal deposits that are thicker, but also show some alternation in their degree of development between adjacent camerae. The internal moulds of several specimens [NMW2019.6G.81 (Fig. 7J), 84 (Fig. 7L), 107 (Fig. 7Q, R), 118 (Fig. 7S, T), 128 (Fig. $7 \mathrm{~W}-\mathrm{Y}$ ), 129 (Fig. 7U, V)], all of which are less than $8 \mathrm{~mm}$ in diameter appear to represent surfaces resulting from 

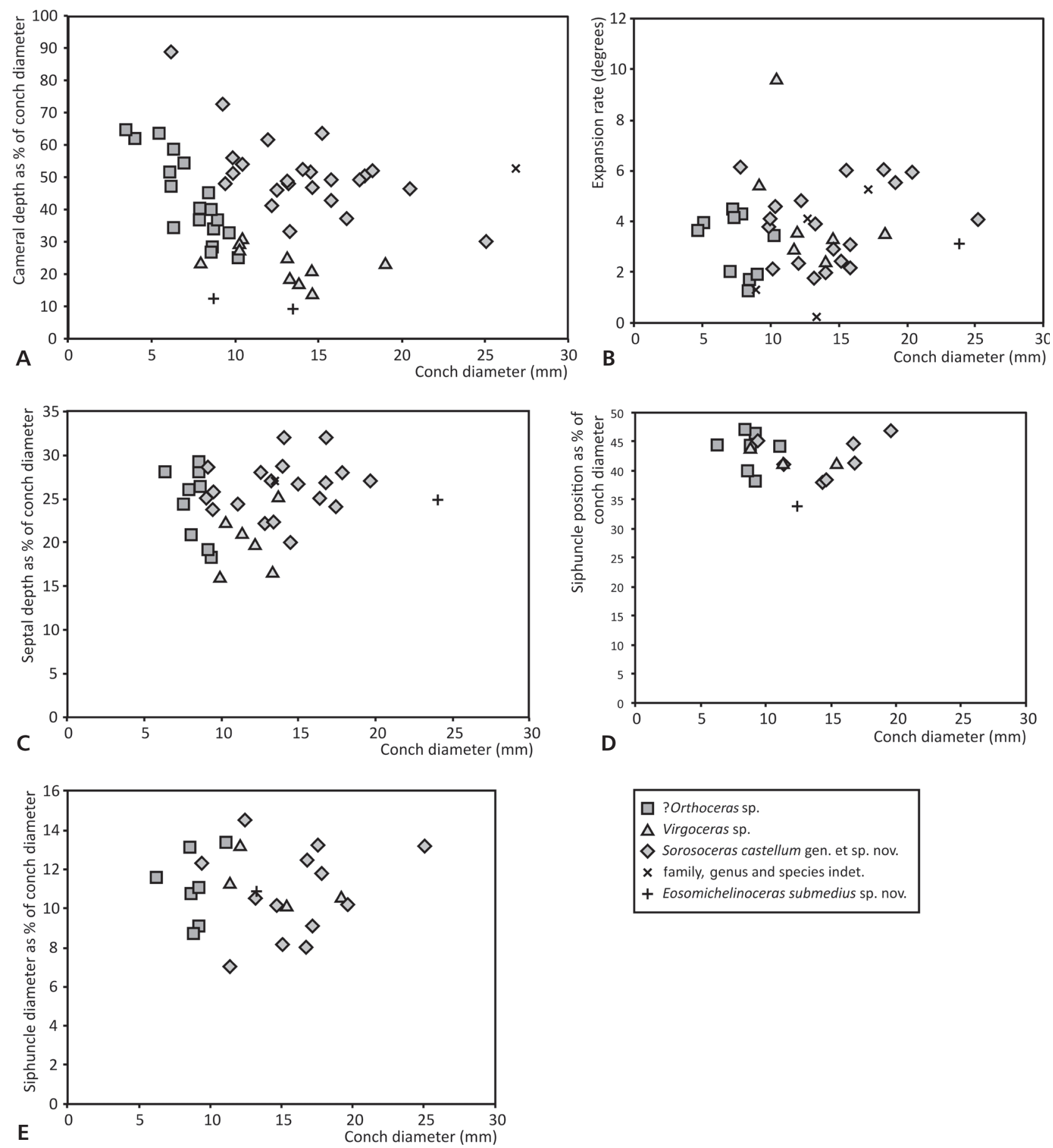

Figure 8. Distribution of various characters across selected cephalopod taxa from the Pelmis Formation. • A - variation of cameral depth with conch diameter. $\bullet \mathrm{B}$ - distribution of conch expansion rates with conch diameter. $\bullet \mathrm{C}-$ variation of septal depth with conch diameter. $\bullet \mathrm{D}-\mathrm{variation}$ of the position of the siphuncle with conch diameter. $\bullet$ - variation of the diameter of the siphuncle at the septal foramen with conch diameter.

the exfoliation of mural cameral deposits. Exfoliation combined with the adapical increase in the thickness of the mural deposits give a false impression that the conchs possess relatively high initial rates of expansion. The exfoliated mural surfaces visible on NMW2019.6G.121
(Fig. 7I) show moulds of a finely mammilated texture representing the surfaces of the mural episeptal deposits.

As no specimen exhibits any convincing remains of the conch surface, the nature of the shell sculpture (if any) remains unknown. 
Remarks. - Orthoceras and the Orthoceratinae have been diagnosed (Sweet 1964) on the basis of the longitudinal impressions on the body-chamber. While Flower (1962) demonstrated the presence of incipient episeptal cameral deposits at a phragmocone diameter of $9 \mathrm{~mm}$ in one of the specimens used in Troedsson's description of the type species (Troedsson 1931). Flower also considered that thin mural deposits were present but had been lost through exfoliation. No endosiphuncular deposits were observed. Descriptions of specimens ascribed to Orthoceras regulare Schlotheim, 1820 or Orthoceras (sensu stricto) (Dzik 1984, Kröger 2004) were illustrated showing well developed cameral and endosiphuncular deposits at phragmocone diameters ranging from 6-10 mm. Although Kröger (2004) described material from Troedsson's collection, his only illustration of the apical end of an individual ascribed to $O$. regulare is from a Polish glacial erratic. Dzik (1984) regarded the cameral and endosiphuncular deposits present in orthocerids as being so variable as to be of little diagnostic value, while he also observed that his associating of the bodychambers with particular apical portions of phragmocone was tentative. Thus it remains the case that Flower's study (1962) of the material described by Troedsson provides the only example where the more apical portions of the phragmocone can be positively associated with the body-chamber in Orthoceras regulare. The nature of the endosiphuncular deposits in Orthoceras regulare remains unknown, although the cameral deposits are known to be episeptal and mural.

No body-chambers diagnostic of Orthoceras have been recognized in the assemblage. The lack of any conchs in which the shell sculpture is preserved precludes the recognition of larger conch fragments within the assemblage than those described here. However, in terms of the size and position of the siphuncle and depth of the camerae these more apically positioned conch fragments could be assigned to either $O$. regulare or $O$. bifoveatum Noetling, 1884.
Family Geisonoceratidae Zhuravleva, 1959

\section{Genus Virgoceras Flower, 1939}

[? = Archigeisonoceras Chen, 1984]

Type species. - Orthoceras palemon Barrande 1870, pl. 394 , from the Silurian of Bohemia. By original designation.

Remarks. - In discussing the status of Virgoceras, Evans et al. 2013) concluded that Archigeisonoceras Chen, 1984 was a probable junior synonym, and that the Middle Ordovician taxa described from Sweden under Archigeisonoceras by Kröger (2004) were probably representatives of Virgoceras.

\section{?Virgoceras sp. sensu Evans et al. (2013)}

Figures 5G, K, L; 7Z, A*-E*; 9A-G

2013 ?Virgoceras sp. A. - Evans et al. p. 34, figs 5n, o, v, $\mathrm{w}, \mathrm{c}^{*}, \mathrm{~d}^{*}, \mathrm{e}^{*}, \mathrm{f}^{*} ; 8 \mathrm{a}, \mathrm{b}, \mathrm{m}, \mathrm{o} ; 9 \mathrm{~b}, \mathrm{~d} ; 10 \mathrm{a}-\mathrm{e}, 1$.

1981 Orthoceras vagans Salter. - Kalantari, pl. 2, figs 5-14.

Material. - Thirteen individuals: NMW2019.6G.4, 17, 26, $33,41,45,49,58,65,83,88,90,93$. All consist of internal moulds of phragmocones.

Description. - The apical angles of these individuals range from $4^{\circ} 50^{\prime}-9^{\circ} 27^{\prime}\left(\right.$ mean $=6^{\circ} 30^{\prime} ; \mathrm{N}=10$; Fig. 8B). Cameral depth decreases adorally from $33.9 \%$ of the phragmocone diameter to $14.0 \%$ (Fig.8A). The depth of the septa ranges from $16.6-25.2 \%$ (mean $=20.54 \% ; \mathrm{N}=$ 10; Fig. 8C). The diameter of the siphuncle at the septal foramen ranges from $7.7-13.4 \%$ of the phragmocone diameter (Fig. 8E) and may decrease in diameter with ontogeny. Nothing is known of the shape of the connecting rings as they are not preserved in those specimens that have been sectioned. The septal necks appear to be short $(0.25 \mathrm{~mm})$ and orthochoanitic adapically (Fig. $5 \mathrm{~L})$, but aneuchoanitic adorally. The ventral sides of the septal

Figure 9. Cephalopods from the Pelmis Formation. $\bullet \mathrm{A}-\mathrm{G}-$ ? Virgoceras sp.; A, B - dorsal and lateral views of phragmocone, the former showing septal furrows (see also Fig. 6B*), NMW 2019.6G.26, scale bar $=10 \mathrm{~mm}$; C, D - lateral and ventral view of phragmocone, NMW 2019.6G.41, scale bar $=$ $10 \mathrm{~mm}$; E-G - worn longitudinal section through phragmocone and lateral and partial ventral views, NMW 2019.6G.93, scale bar $=10 \mathrm{~mm}$. $\bullet$ H-A*, $\mathrm{H}^{*-}-\mathrm{L}^{*}$ - Sorosoceras castellum gen. et sp. nov.; H, I, J*, K* - NMW 2019.6G.28, (?)ventral and apical views, scale bar $=10 \mathrm{~mm}(\mathrm{H}, \mathrm{I}, \mathrm{K} *)$; J* - detail of shell sculpture, scale bar $=10 \mathrm{~mm} ; \mathrm{K}^{*}-$ lateral view, scale bar $=10 \mathrm{~mm} ; \mathrm{J}, \mathrm{K}-$ apical and lateral views of portion of phragmocone, scale bar $=$ $10 \mathrm{~mm} ; \mathrm{L}, \mathrm{M}$ - dorsal and ventral views of phragmocone, NMW 2019.6G.2, scale bar $=10 \mathrm{~mm} ; \mathrm{N}, \mathrm{O}-$ dorsal and lateral views of phragmocone, NMW 2019.6G.125, scale bar = 10 mm; P, Q, R - dorsal, ventral and apical views of phragmocone, NMW 2019.6G.126, scale bar = 10 mm; S, T, U - NMW 2019.6G.125, apical and lateral views (S, T) of crushed phragmocone (scale bar $=10 \mathrm{~mm}$ ), detail of shell sculpture $(\mathrm{U}, \mathrm{scale}$ bar $=2 \mathrm{~mm}) ; \mathrm{V}-$ dorsal view of phragmocone showing dorsal furrows, NMW 2019.6G.114, scale bar $=10 \mathrm{~mm}$; W - lateral view of phragmocone (venter on left) showing partially exfoliated mural cameral deposits and the molds of bosses formed by developing episeptal deposits arranged symmetrically either side of the dorsoventral plane of the conch, NMW 2019.6G.111, scale bar $=5 \mathrm{~mm} ; \mathrm{X}, \mathrm{Y}, \mathrm{Z}-\mathrm{NMW} 2019.6 \mathrm{G} .120$, lateral and apical views $(\mathrm{X}, \mathrm{Y}$, scale bar $=10 \mathrm{~mm})$, conch sculpture $(Z$, scale bar $=2 \mathrm{~mm}) ; \mathrm{A}^{*}-$ ventral view of internal mold of phragmocone with molds of mammilate episeptal cameral deposits visible, NMW 2019.6G.108, scale bar $=5 \mathrm{~mm} ; \mathrm{H}^{*}$ - shell sculpture, NMW 2019.6G.1, scale bar $=2 \mathrm{~mm}$; I* - lateral view of phragmocone, NMW 2019.6G.96, scale bar $=5 \mathrm{~mm} . \mathrm{B}^{*}-\mathrm{G}^{*}-$ Fam., gen. et sp. indet.; $\mathrm{B}^{*}, \mathrm{~F}^{*}, \mathrm{G}^{*}-$ apical, ventral and dorsal views of part of body-chamber and most adoral camerae, NMW 2019.6G.4, scale bar $=10 \mathrm{~mm} ; \mathrm{C}^{*}-\mathrm{E}^{*}-$ ventral, dorsal and apical views of a deformed phragmocone, NMW 2019.6G.23, scale bar $=2.5 \mathrm{~mm}$. 


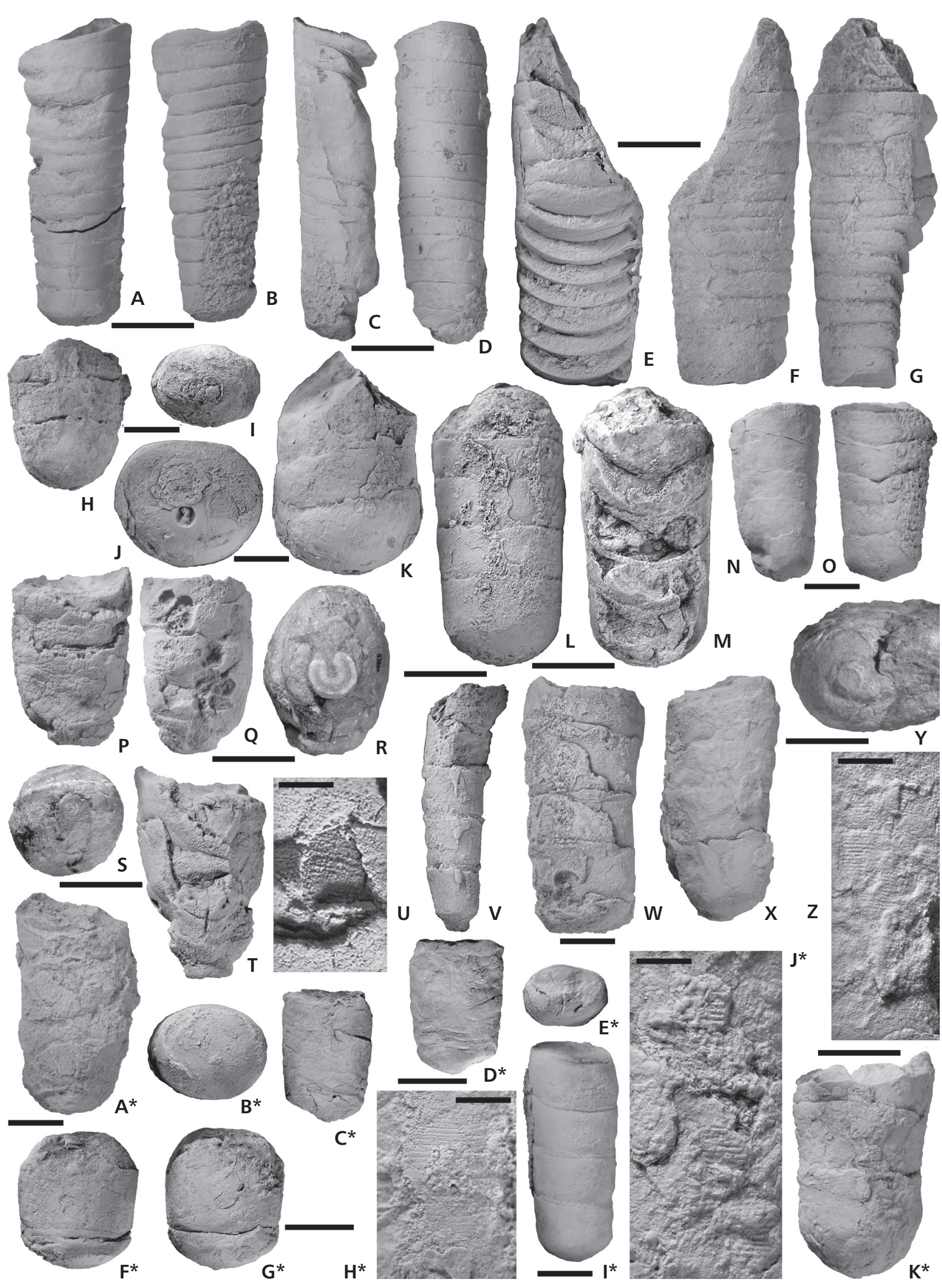


foraminae lie between $41 \%$ and $44 \%$ of the diameter of the phragmocone (Fig. 8D).

Cameral deposits are evident in three of the specimens (NMW2019.6G.26, 33, 45). Two of these specimens (NMW2019.6G.26 and 45) have been subjected to a degree of deformation so that the cameral deposits are partially displaced and the venter is largely missing.

The mould of the septal surface at the apical end of NMW2019.6G.33 (7.5 $\mathrm{mm} \mathrm{dia)} \mathrm{shows} \mathrm{that} \mathrm{a} \mathrm{thin} \mathrm{episeptal}$ cameral deposit was originally present. The deposit is marginally thicker on the ventral side of the phragmocone, but is distributed almost around its entire circumference. No episeptal deposits are present for a width of about $0.3 \mathrm{~mm}$ either side of the venter, but beyond this zone cameral deposits extend across the episeptal surface in a to a distance about halfway between the conch wall and the septal foramen, so that a cleft is formed that extends from the venter towards the conch axis.

Episeptal cameral deposits in NMW2019.6G.26, where seen in section Fig. 5K), are thin on the dorsal side of the conch and extend onto the episeptal surface to about halfway to the septal foramen. On the ventral side episeptal deposits thicken toward the venter to reach a thickness about half that of the depth of the camerae. Where visible (Fig. 7C*), moulds of the surface of the episeptal deposits have a finely mammilate texture. No hyposeptal deposits are evident. While the extent of development of cameral deposits decreases adorally, this is not a progressive sequence, and instead the deposits may be less well or better developed in adorally adjacent camerae.

In NMW2019.6G.45 the septal furrows are visible (Fig. 7A*), while cameral deposits are well-developed on the opposite (ventral) side of the phragmocone (Fig. $7 \mathrm{~B}^{*}$ ). In this specimen, episeptal deposits consist of a row of botryoidal masses arranged symmetrically either side of the venter, so that the distance between the conch wall and inner margin of the deposits is at a minimum over the venter and increases either side of the venter to form a pair of ventrolateral masses. The height of these masses diminishes laterally to form a thin, even layer that appears to terminate on the lateral flanks of the phragmocone. Nothing is known of the conch sculpture.

Remarks. - In general form, the specimens described above are most similar to ?Virgoceras sp. A from the Shirgesht Formation of the Derenjal Mountains and the Lashkarak Formation of the eastern Alborz, described by Evans et al. (2013). There are some differences however. The depth of the apical camerae in the material described here is much shallower, while the ontogenetic changes in the morphology of the septal necks appears to be the reverse of that seen in ?Virgoceras sp. A. However, these differences may reflect the lack of sufficient sectioned material to demonstrate the full range of variation in this taxon.

\section{Genus Sorosoceras gen. nov.}

Type species. - Sorosoceras castellum sp. nov.

Etymology. - After the Kopet-Dagh mountain range of north-eastern Iran. Kopet or koppeh, meaning pile or heap in Persian, or soros in ancient Greek.

Diagnosis. - Longicones expanding at about $4^{\circ}$; camerae moderately deep adapically; septa approximately one third of the conch diameter in depth. Siphuncle slightly displaced from conch axis apically, becoming increasingly distant adorally. Diameter of septal foramen about $11 \%$ of the conch diameter. Septal necks orthochoanitic to suborthochoanitic. Connecting rings barrel-shaped, tapering slightly adapically in each segment; inflated up to 1.9 times that of the septal foramen. Endosiphuncular deposits of discrete annuli at septal necks then developing into adorally accreting parietal deposits. Cameral deposits episeptal, mural and hyposeptal. Endosiphuncular deposits developed in advance of cameral deposits. Conch sculpture of transverse lirae with a rounded cross-section when narrow and flat-topped when wide; separated by rounded interspaces that vary in form from broad depressions to narrow grooves.

Remarks. - In the possession of an inflated siphuncle containing endosiphuncular deposits that develop in advance of the cameral deposits and are composed of annuli that later extend adorally as parietal deposits, Sorosoceras is similar to Kinnekulloceras Kröger, 2004. Prior to Kröger's publication of Kinnekulloceras the name had existed in the manuscripts and notes of Holm and Foord (Andrew H. King, personal communication 2019). King (1990) redescribed the type material of Orthoceras kinnekullense Foord, 1887 together with additional material from the Kundan Stage of Västergötland and Dalarna (Sweden), assigning them to the manuscript genus Kinnekulloceras, and later (King 1999, fig. 6d) illustrating one of these specimens as "Geisonoceras" kinnekullense (Foord). Kröger's description of K. kinnekullense is at variance with that of King (1990) both in the nature of the conch sculpture, the diameter of the septal foramen, and the degree of inflation of the connecting rings. Other than NRM-Mo 155245, Kröger did not indicate the accession numbers of the seventeen specimens from the Naturhistoriska Riksmuseet (Stockholm) that he assigned to K. kinnekullense. NRM-Mo 155245 was not one of the specimens cited by King (1990) and exhibits connecting rings that are only weakly inflated by comparison with the material assigned to his manuscript Kinnekulloceras. Thus, other than Foord's type specimens, it is unclear whether any of the specimens included in Kinnekulloceras by Kröger can be assigned to the species or the genus. 
Sorosoceras is distinct from Kinnekulloceras in possessing a siphuncle that is narrower at the septal foraminae. The connecting rings are inflated to a similar degree, but taper slightly apically. Most significantly, the conch sculpture in Sorosoceras consists of discrete, rounded ribs where the tops may be slightly flattened, but has much broader and rounded interspaces than those seen in Kinnekulloceras, so that the conch sculpture is similar to many other geisonoceratids.

\section{Sorosoceras castellum sp. nov.}

Figures 5F, H, J, M, N; 9H-A*, $\mathrm{H}^{*}-\mathrm{L}^{*}$

Types. - Syntypes NMW2019.6G.1, 2, 28, 120, 125, 126.

Type horizon and locality. - Limestone at the base of the stratotype section of the Pelmis Formation (Unit P2). Kalat river valley; eastern part of the Saluk area, $37^{\circ} 13^{\prime} 49^{\prime \prime} \mathrm{N}$, $57^{\circ} 23^{\prime} 3^{\prime \prime}$ E, Iran.

Other material. - NMW2019.6G. 5, 6, 13, 21, 27, 35, 36, 61, 69, 70, 73, 96, 108, 111, 114, 127.

Etymology. - Castellum, Latin for castle, referring to Kalat village (Kalat, meaning castle in Persian), near to the location of the Pelmis section.

Diagnosis. - As for genus.

Description. - The available specimens consist of pieces of orthoconic phragmocone with small apical angles $[$ mean $=$ $4^{\circ} 25^{\prime} ; \max =8^{\circ} 36^{\prime} ; \min =1^{\circ} 40^{\prime} ; \mathrm{N}=12$ (Fig. 8B)] and camerae that decrease in depth (Fig. 8A) from around $65 \%$ at a conch diameter of $8 \mathrm{~mm}$ to $24 \%$ at a diameter of $27 \mathrm{~mm}$. The mean depth of the septa is $25.9 \%$ of the conch diameter $(\mathrm{N}=17)$. The diameter of the siphuncle at the septal foramen varies between $8 \%$ and $13.1 \%$ of the conch diameter $[$ mean $=11.16 ; \mathrm{N}=12$ (Fig. 8C)]. The location of the siphuncle lies between $38-46 \%$ of the distance across the phragmocone (mean $=43.38 \% ; \mathrm{N}=8$ ), and migrates away from the conch axis with the growth of the conch (Fig. 8D).

The overall morphology of the siphuncle is best seen in NMW2019.6G.125 (Fig. 5N). Here, the suborthochoanitic septal necks are visible and are slightly longer dorsally $(0.94 \mathrm{~mm})$ than ventrally $(0.83 \mathrm{~mm})$, while the respective widths of the brims are $0.70 \mathrm{~mm}$ and $0.56 \mathrm{~mm}$. The connecting ring is barrel-shaped, and in the adoral quarter of the segment, has a diameter 1.9 times that of the septal foramen, tapering apically to 1.6 before being strongly deflected toward the septal foramen. Discrete endosiphuncular annuli are visible at the septal necks in NMW2019.6G.35, 125-126 (Fig. 5F, H, N), while in NMW2019.6G.126 (Fig. 5H) the annuli extend adorally into the siphuncular segments as parietal deposits that are more strongly developed on the ventral than the dorsal surfaces of the connecting rings.

Cameral deposits are visible in several specimens, either in section or as part of the internal mould of the phragmocone. As a consequence of the brittle deformation of the shell combined with diagenetic alterations to the cameral deposits and matrix, the distribution of these deposits can be difficult to interpret in polished sections. In the four individuals where cameral deposits are visible, the conch diameter ranges from $8.3 \mathrm{~mm}$ to $13.2 \mathrm{~mm}$. Extensive episeptal and mural deposits are present in NMW2019.6G.126 (diameter $12.5 \mathrm{~mm}$ ). These decrease in volume adorally. In NMW2019.6G.35 (diameter $13.2 \mathrm{~mm}$ ) extremely thin episeptal and hyposeptal deposits are developed (Fig. 5F). The hyposeptal deposits extend closer to the conch axis than the episeptal deposits, but do not extend as far as the conch wall in the other direction. A crushed internal mould (NMW2019.6G.108; diameter $10.1 \mathrm{~mm}$ ) shows episeptal cameral deposits in the form of a mould with a mammilate surface extending over the ventral side of the septum (Fig. 9A*). On the mural surface, the mammilation is of a finer texture. One individual (NMW2019.6G.114; dia. $8.3 \mathrm{~mm}$ ) shows a dorsal furrow (Fig. 5V), while very thin and finely mammilate mural deposits are present on the ventral surface of the mould. NMW2019.6G.126, the only specimen where cameral deposits are extensively developed, is also the only specimen to show well-developed parietal deposits in addition to annulosiphonate deposits (Fig. 5H). Comparison with NMW2019.6G.35, where the cameral and annulosjphonate deposits are incipient indicates that the parietal deposits develop at a relatively late stage. In NMW2019.6G.35 (Fig. 5F) the most adoral septal foraminae, although separated from the rest of the septum possess annulosiphonate deposits, while no cameral deposits are evident, indicating that the annulosiphonate deposits are developed in advance of the cameral deposits.

Patches of the conch surface is preserved in four specimens: NMW2019.6G.1 (Fig. 9H*), G.28 (Fig. 9J*, K*), G.120 (Fig. 9Z) and G.125 (Fig. 9U). All four specimens exhibit fine transverse rounded to flat-topped ribs with densities of 7 per $\mathrm{mm}$ (diameter $13.65 \mathrm{~mm}$ ), 5 per $\mathrm{mm}$ (diameter $20 \mathrm{~mm}$ ), 8 per $\mathrm{mm}$ (diameter $17.5 \mathrm{~mm}$ ) and 8 per $\mathrm{mm}$ (diameter $9.1 \mathrm{~mm}$ ) respectively. The ribs range in width from $0.12 \mathrm{~mm}$ (NMW2019.6G.1) to $0.03 \mathrm{~mm}$ (NMW2019.6G.120) so that the intervening areas range from narrow grooves to broader, shallower and rounded depressions.

Remarks. - As for genus.

Gen. et sp. indet.

Figure $9 \mathrm{~B}^{*}-\mathrm{G}^{*}$ 
Material. - Two extremely fragmentary specimens, NMW2019.6G.23, 44.

Description. - NMW2019.6G.23 (Fig. 9C*-E*) is a $20 \mathrm{~mm}$ long fragment of conch consisting of phragmocone. In the adoral $14 \mathrm{~mm}$ the septa have been broken and now lie packed together next to the first reasonably intact septum. The conch is depressed in section $(8.5 \mathrm{~mm}$ by $12.5 \mathrm{~mm}$ at the base of the body-chamber) but is probably partially crushed so that the degree of compression is exaggerated. The sutures are transverse and straight and in those septa that remain more or less intact, the depth of the camerae is $12 \%$ that of the dorsoventral diameter of the phragmocone. Since the conch has been crushed to some extent, this value is likely to be an overestimate. Nothing is known regarding the location and structure of the siphuncle, since the septa are too badly crushed to locate the septal foramen or any related structures.

The second specimen, NMW2019.6G.44 (Fig. 9B*, F*, $\mathrm{G}^{*}$ ) consists of a portion of conch $21 \mathrm{~mm}$ long comprising an incomplete body-chamber phragmocone and a single camera $1.25 \mathrm{~mm}$ in depth. The conch has a depressed cross-section that is 14 by $17 \mathrm{~mm}$ at the apical end of the preserved portion and is slightly flattened on the ventral and dorsal surfaces. There is nothing to suggest that the crosssection profile is the consequence of deformation. There is a faint band that maintains a width of $0.8 \mathrm{~mm}$ wide around the circumference of the apical end of the body-chamber and may represent the annular elevation. The only camera present has a depth $9 \%$ that of the dorsoventral conch diameter. The suture is transverse and straight. A mould of the septal foramen is visible on the septum which has a diameter $11 \%$ that of the dorsoventral conch diameter, while being situated at $41 \%$ of the way across the conch from the venter. Faint traces of the conch sculpture remain in small patches on the surface of the body chamber. What little remains suggests that the shell was almost smooth with extremely fine growth lines.

Remarks. - There are a limited number of taxa possessing depressed cross-sections combined with a sub-central siphuncle lying towards the venter. These include (amongst others) Allumettoceras Foerste, 1926; Hoeloceras Sweet, 1958 and Pseudowutinoceras Chen, 1976. Of these, both Hoeloceras and Pseudowutinoceras have much more marginally positioned siphuncles than seen in the material described above, while the depth of the camerae is similar. These specimens are similar to Allumettoceras in the position of the siphuncle, but the depth of the camerae is much shallower than that seen in in other species of that genus. Without additional, better-preserved material, the identity of these specimens will remain uncertain although they clearly represent a distinct element of the cephalopod assemblage of the Ghelli Formation.

\section{Acknowledgements}

The authors thank reviewers Björn Kröger (University of Helsinki) and Štěpán Manda (Czech Geological Survey) for their critical and constructive comments that have helped significantly improve parts of the final manuscript.

\section{Refererences}

Afshar-Harb, A. 1979. The Statigraphy, Tectonics and Petroleum Geology of Kopet-Dagh region. 316 pp. Ph.D. thesis, Imperial Collage of Science and Technology, University of London, U.K.

Angelin, N.P. \& Lindström, G. 1880. Fragmenta Silurica. 66 pp. Sampson \& Wallin, Stockholm.

Ahmadzadeh-Heravi, M. 1983. Brachiopods and conodonts from Lower Palaeozoic sediments in southern Bojnourd. Journal of Technology and Science, Tehran University 45, 1-24. [in Persian]

Barrande, J. 1865-1877. Systême Silurien du centre de la Bohême. Vol. II. Céphalopodes. Texte: 1867, part 1, 712 pp.; 1870, part 2, 263 pp.; 1874, part 3, 804 pp.; 1877, part 4, 742 pp.; 1877, part 5, 743 pp.; supplement: 1877, 297 pp.; 1865, pls $1-107 ; 1866$, pls $108-244 ; 1868$, pls 245-350; 1868, pls $351-460 ; 1870$, pls $351-460 ; 1877$, pls 461-544. Privately published, Prague \& Paris.

Bayet-Goll, A. \& Neto De Carvalho, C. 2016. Ichnology and sedimentology of a tide-influenced delta in the Ordovician from the northeastern Alborz range of Iran (Kopet Dagh region). Lethaia 49, 327-350.

DOI 10.1111/let.12150

Bogolepova, O.K., Kröger, B., Falahatgar, M. \& Javidan, M. 2014. Middle Ordovician cephalopods from the Abarsaj area, northern Iran. GFF 136, 34-37. DOI 10.1080/11035897.2014.898328

Bruguière, J.G. 1789. Histoire naturelle des vers. Volume 1, Part 1, Encyclopedie methodique 6.757 pp. Panckoucke, Paris. DOI 10.5962/bhl.title.53769

CHen, J.Y. 1974. Ordovician Nautiloidea, 138-143. In NIGPAS (ed.) A Handbook of the Stratigraphy and Paleontology in Southwest China. Science Press, Beijing.

Chen, J.Y. 1976. Advances in the Ordovician stratigraphy of North China with a brief description of nautiloid fossils. Acta Palaeontologica Sinica 15, 55-74.

Chen, T.E. 1984. The Ordovician cephalopod fauna and the subdivision of Ordovician from souther Xizang (Tibet). Acta Palaeontologica Sinica 23, 453-471.

Chen, T.E. \& ZHou, X. 1984. On the Baota (Pagoda) Formation, 467-498. In NIGPAS (ed.) Stratigraphy and palaeontology of Systemic Boundaries in China: Ordovician - Silurian Boundary (1). Anhui Science and Technology Publishing House, Anhui.

Dastanpour, M., Evans, D.H. \& Bassett, M.G. 2006. A new orthoceratoid cephalopod from the Ordovician (Caradoc) of east-central Iran. Geobios 39, 337-345.

DOI 10.1016/j.geobios.2004.11.008 
DzIK, J. 1984. Phylogeny of the Nautiloidea. Palaeontologia Polonica 45, 1-203.

Evans, D.H., Ghobadi Pour, M. \& Popov, L.E. 2013. Review of the Early to Mid Ordovician orthoconic cephalopods from Iran. Bulletin of Geosciences 88, 21-44. DOI 10.3140/bull.geosci.1355

Evans, D.H., Ghobadi Pour, M., Popov, L.E. \& JahangiR, H. 2015. An Early Silurian (Aeronian) cephalopod fauna from Kopet-Dagh, north-eastern Iran: including the earliest records of non-orthocerid cephalopods from the Silurian of Northern Gondwana. Bulletin of Geosciences 90(2), 479-507. DOI 10.3140/bull.geosci.1540

Flower, R.H. 1939. Study of the Pseudorthoceratidae. Palaeontologica Americana 2, 101-214.

Flower, R.H. 1946. Ordovician cephalopods of the Cincinnati region. Part I. Bulletins of American Paleontology 29, 1-656.

Flower, R.H. 1962. Notes on the Michelinoceratida. New Mexico Bureau of Mines and Mineral Resources, Memoir 10, 21-55.

Foerste, A.F. 1926. Actinosiphonate, trochoceroid, and other cephalopods. Denison University Bulletin, Journal of the Science Laboratory 21, 285-384.

Foord, A.H. 1887. On Endoceras duplex Wahl., with descriptions of three new species of Endoceras from the Ordovician of Sweden and Russia contained in the British Museum. Annals and Magazine of Natural History Series 20(120), 393-402. DOI 10.1080/00222938709460083

Ghavidel-Syooki, M. 2001. Palynostratigraphy and Paleobiogeography of the Lower Palaeozoic sequence in the northeastern Alborz Range (Kopet-Dagh region) of Iran, 17-35. In Goodman, D.K., Clarke, R.T. (eds) Proceedings of the IX International Palynological Congress Houston, Texas, USA, 1996. 618 pp. American Association of Stratigraphic Palynologists Foundation.

GHAVIDEL-SYooKi, M. 2017a. Stratigraphic evidence for Hirnantian glaciation in the Alborz Mountain Ranges, northeastern Iran. Palaeogeography, Palaeoclimatology, Palaeoecology 485, 879-898. DOI 10.1016/j.palaeo.2017.08.004

Ghavidel-Syooki, M. 2017b. Cryptospore and trilete spore assemblages from the Late Ordovician (Katian-Hirnantian) Ghelli Formation, Alborz Mountain Range, Northeastern Iran: Palaeophytogeographic and palaeoclimatic implications. Review of Palaeobotany and Palynology 244, 217-240. DOI 10.1016/j.revpalbo.2017.05.010DOI

GHavidel-Syooki, M. \& BorJi, S. 2018. Chronostratigrahy of acritarchs and chitinozoans from upper Ordovician strata from the Robat-e Gharabil Area, NE Alborz Mountains, Northern Khorassan Province: Stratigraphic and Paleogeographic Implications. Journal of Sciences, Islamic Republic of Iran 29, 35-51.

Ghavidel-Syooki, M. \& Winchester-Seeto, T. 2002. Biostratigraphy and palaeogeography of Late Ordovician chitinozoans from the northeastern Alborz Range, Iran. Review of Palaeobotany \& Palynology 118, 77-99. DOI 10.1016/S0034-6667(01)00108-7

Ghavidel-Syooki, M., Evans, D.H., GhobadiPour, M.,Popov,L.E., Álvaro, J.J., Rakhmonov, U., Klishevich, I.A. \& Ehsani, M.H. 2015. Late Ordovician cephalopods, tentaculitides, machaeri- dians and echinoderms from Kuh-e Faraghan, High Zagros, Iran. Alcheringa 39, 530-549.

DOI 10.1080/03115518.2015.1052677

Ghobadi Pour, M., Popov, L.E., Zadeh, M.R.K. \& BaArs, C. 2011. Middle Ordovician (Darriwilian) brachiopods associated with the Neseuretus biofacies, eastern Alborz Mountains, Iran. Memoirs of the Association of Australasian Palaeontologists 42, 263-283.

Hall, J. 1847. Descriptions of the organic remains of the lower division of the New York system. Palaeontology of New York. Volume 1.338 pp. C. Van. Benthuysen. Albany, New York.

Hairapetian, V., Ghobadi Pour, M., Popov, L.E., Männik, P. \& Miller, C.G. 2017. Silurian stratigraphy of Central Iran - an update. Acta Geologica Polonica 67, 201-233. DOI 10.1515/agp-2017-0014

HavlíčEK, V. 1981. Upper Ordovician brachiopods from the Montagne Noire. Paleontographica, Abteilung A 176, 1-34.

Jahangir, H., Ghobadi Pour, M.G., Holmer, L.E., Popov, L.E., Ashuri, A.R., Rushton, A., Tolmacheva, T.Y. \& Amini, A., 2015. Biostratigraphy of the Cambrian-Ordovician boundary beds at Kopet-Dagh, Iran. Stratigraphy 2, 40-47. DOI 10.1080/03115518.2016.1118298

KalantaRI, A. 1981. Iranian fossils. Geological Laboratories Publication 9. 216 pp. Ministry of Oil, National Iranian Oil Company, Tehran.

KING, A.H. 1990. Lower and Middle Ordovician Cephalopoda of Baltoscandia. Ph.D. thesis, University of Wales, Swansea.

KING, A.H. 1999. A review of Volkhovian and Kundan (ArenigLlanvirn) nautiloids from Sweden, 137-159. In OLÓRIZ, F. \& Rodriguez-Tovar, F.J. (eds) Advancing research on living and fossil cephalopods. 550 pp. Kluwer Academic/Plenum Publishers, New York. DOI 10.1007/978-1-4615-4837-9_11

Kobayashi, T. 1935. Restudy on Manchuroceras with a brief note on the classification of Endoceroids. Geological Society of Japan, Journal 42, 436-452.

DOI 10.5575/geosoc. 42.736

KRÖGER, B. 2004. Revision of Middle Ordovician orthoceratacean Nautiloids from Baltoscandia. Acta Palaeontologica Polonica 49, 57-74.

KRÖGER, B. 2013. The cephalopods of the Boda Limestone, Late Ordovician, of Dalarna, Sweden. European Journal of Taxonomy 41, 1-110. DOI 10.5852/ejt.2013.41

Kröger, B. \& IsAKar, M. 2006. Revision of annulated orthoceridian cephalopods of the Baltoscandian Ordovician. Fossil Record 9, 137-163. DOI 10.1002/mmng.200600005

KRÖGER, B., BerEsi, M.S. \& LANDING, E. 2007. Early orthoceratoid cephalopods from the Argentine Precordillera (Lower-Middle Ordovician). Journal of Paleontology 81, 1263-1280. DOI 10.1666/06-013.1

Kröger, B., Ebbestad, J., Högström, A.E.S. \& Frisk, Å. 2011. Mass concentration of Hirnantian cephalopods from the Siljan District, Sweden; taxonomy, palaeoecology and palaeobiogeographic relationships. Fossil Record 14, 35-53. DOI 10.1002/mmng.201000014

Kunn, O. 1940. Paläozoologie in Tabellen. 50 pp. G. Fischer, Jena.

Lin, B.Y. \& QIU, H.R. 1982. A new recognition of the Palaeozoic 
stratigraphy in Himalaya districts of Xizang (Tibet), 149-152. Geological Contributions Qinghai-Xizang (Tibet) Plateau 5. [in Chinese with English abstract]

McCoy, F. 1844. A synopsis of the characters of the Carboniferous Limestone fossils of Ireland. 207 pp. Dublin University Press; Dublin. DOI 10.5962/bhl.title.11559

Noetling, F. 1884. Beiträge zur Kenntniss der Cephalopoden aus Silurgeschieben der Provinz Ost-Preussen. Jahrbuch der Königlich Preussischen Geologischen Landesanstalt und Bergakademie zu Berlin 1883, 101-135.

Popov, L.E., Hairapetian, V., Evans, D.H., Ghobadi Pour, G., Holmer, L.E. \& BaArs, C. 2015. Review of the Ordovician stratigraphy and fauna of the Anarak Region in Central Iran. Acta Geologica Polonica 65, 403-435.

DOI 10.1515/agp-2015-0019

Schlotheim, E.F. von 1820. Die Petrefactenkunde auf ihrem jetzigen Stand - punkte durch die Beschreibung seiner Sammlung versteinerter und fossiler Überreste des Tier - und Pflanzenreichs der Vorwelt erläutert. 437 pp. Gotha.

Seilacher, A. 1969. Sedimentationprozesse in Ammoniten. Akademie der Wissenschaften und der Literatur, Mainz 9, 191-203.

SweEt, W.C. 1958. The Middle Ordovician of the Oslo region of Norway. 10. Nautiloid cephalopods. Norsk Geologiske Tidsskrift 31, 1-178.

SweEt, W.C. 1964. Orthocerida, 216-261. In Moore, R.C. (ed.) Treatise on invertebrate paleontology. Part K. Mollusca 3,
Cephalopoda. General features, Endoceratoidea, Actinoceratoidea, Nautiloidea, Bactritoidea. 519 pp. Geological Society of America and University of Kansas Press, Boulder \& Lawrence, Kansas.

Teichert, C. 1933. Der Bau der actinoceroiden Cephalopoden. Palaeontographica Abteilung A 78, 111-230.

Troedsson, G.T. 1931. Studies on Baltic fossil cephalopods. 1. On the nautiloid genus Orthoceras. Lunds Universitets Arsskrift NF 2 27(16), 1-34.

Wang, R. 1981. Stratigraphic Summary of the Southwestern Region of China. 14-61 pp. Institute of Geology and Mine Deposits at Chengdu, Ministry of Geology.

Wolfart, R. 1970. Fauna, Stratigraphie und Paläogeographie des Ordoviziums in Afghanistan. Beiheft zum geologischen Jahrbuch 89, 1-125.

Yun, C.S. 2011. Ordovician cephalopods from the Jigunsan Formation, Taebaek-Yeongwol, Korea. Journal of the Paleontological Society of Korea 27, 149-259.

Zadeh, M.K., Popov, L.E. \& Ghobadi Pour, M. 2017. A new orthide brachiopod genus from the Middle Ordovician of the Alborz Mountains, Iran, GFF 139, 327-332. DOI 10.1080/11035897.2017.1347197

Zhuravleva, F.A. 1959. On the family Michelinoceratidae. Materialy k Osnovam Paleontologii 3, 47-48. [in Russian]

Zhuravleva, F.A. 1964. New Ordovician and Silurian cephalopods from the Siberian platform. Paleontological Journal, 4, 87-100. [in Russian] 